\title{
The Carbonate-Hosted Tullacondra Cu-Ag Deposit, Mallow, Ireland
}

\author{
Andressa A. Silva ${ }^{1, *(\mathbb{D})}$, Pedro Cordeiro ${ }^{2} \mathbb{D}$, Sean C. Johnson ${ }^{3,4}\left(\mathbb{D}\right.$, Leonardo E. Lagoeiro ${ }^{1}$, Loretta Corcoran ${ }^{5}$, \\ Antonio Simonetti ${ }^{5}{ }^{(D}$, Patrick A. Meere ${ }^{6}$, Richard Unitt ${ }^{6}$, Laisa Stingelin Colaço ${ }^{1}$ and Anderson M. Santos ${ }^{1}$ \\ 1 Department of Geology, Universidade Federal do Paraná, Curitiba 81531-980, Brazil; \\ leonardo.lagoeiro@gmail.com (L.E.L.); laisastingelin@gmail.com (L.S.C.); \\ and.matias.santos@gmail.com (A.M.S.) \\ 2 Departamento de Ingeniería de Minería, Pontificia Universidad Católica de Chile, \\ Avda Vicunã Mackenna 4860, Santiago 4860, Chile; pedro.cordeiro@ing.puc.cl \\ 3 Irish Centre for Research in Applied Geosciences, School of Earth Sciences, University College Dublin, \\ Belfield, Dublin 4, Ireland; sean.johnson@icrag-centre.org \\ 4 Boliden Mineral AB, Finnforsvägen 4, 93632 Boliden, Sweden \\ 5 Department of Civil and Environmental Engineering and Earth Sciences, University of Notre Dame, \\ South Bay, IN 46556, USA; lcorcora@nd.edu (L.C.); antonio.Simonetti.3@nd.edu (A.S.) \\ 6 School of Biological, Earth and Environmental Sciences, University College Cork, Distillery Fields, \\ North Mall, T23 N73K Cork, Ireland; p.meere@ucc.ie (P.A.M.); r.unitt@ucc.ie (R.U.) \\ * Correspondence: aasg18@gmail.com
}

check for updates

Citation: Silva, A.A.; Cordeiro, P.; Johnson, S.C.; Lagoeiro, L.E.; Corcoran, L.; Simonetti, A.; Meere, P.A.; Unitt, R.; Colaço, L.S.; Santos, A.M. The Carbonate-Hosted Tullacondra Cu-Ag Deposit, Mallow, Ireland. Minerals 2021, 11, 560. https://doi.org/10.3390/ $\min 11060560$

Academic Editor: Nicholas E. Pingitore

Received: 18 April 2021

Accepted: 20 May 2021

Published: 25 May 2021

Publisher's Note: MDPI stays neutral with regard to jurisdictional claims in published maps and institutional affiliations.

Copyright: (c) 2021 by the authors. Licensee MDPI, Basel, Switzerland. This article is an open access article distributed under the terms and conditions of the Creative Commons Attribution (CC BY) license (https:// creativecommons.org/licenses/by/ $4.0 /)$.

\begin{abstract}
The Tullacondra $\mathrm{Cu}-\mathrm{Ag}$ deposit is located on the southern margin of the Lower Carboniferous Irish Midlands orefield and contains historical reserves of approximately $4.2 \mathrm{Mt}$ at $0.7 \% \mathrm{Cu}$ and $27.5 \mathrm{ppm} \mathrm{Ag}$. The deposit is hosted within the hanging wall of a feeder fault, the EW-trending Tullacondra Fault, where sulfides and sulfosalts containing elevated $\mathrm{Cu}, \mathrm{Ag}$, As, and Sb deposited, whereas $\mathrm{Zn}$ and $\mathrm{Pb}$ are nearly absent. The deposition of $\mathrm{Cu}$ sulfides in Tullacondra took place along bedding and bedding-parallel dissolution seams, suggesting an epigenetic mineralization that formed: (a) the Transition Series-hosted mineralized zone containing elevated $\mathrm{Cu}$ associated with $\mathrm{Ag}$, As, and Sb; (b) the Lower Limestone Shale-hosted mineralized zone, Cu-dominated and depleted in other metals, and (c) a near-vertical mineralized zone associated with fractures related to the Tullacondra Fault. Some similarities are shared with Irish-type $\mathrm{Zn}-\mathrm{Pb}$ deposits, such as structural and stratigraphic controls, and elevated $\mathrm{Cu}, \mathrm{Ag}$, $\mathrm{As}$, and $\mathrm{Sb}$ within feeder-fault proximal zones (such as in Lisheen and Silvermines). Whether Tullacondra mineralization was part of the Irish-type system or not, our deposit geometry evaluation, whole-rock geochemistry, paragenetic sequence, and texture relationships indicate that $\mathrm{Cu}$-Ag deposition involved the reaction of metal-bearing fluids with carbonate rocks.
\end{abstract}

Keywords: carbonate-hosted ore deposits; Irish-type deposits; copper; silver; Irish Midlands

\section{Introduction}

The Irish $\mathrm{Zn}-\mathrm{Pb}$ Orefield represents one of the largest grades of $\mathrm{Zn}$ and $\mathrm{Pb}$ per $\mathrm{km}^{2}$ in the world [1]. The orefield includes the Navan, Lisheen, and Silvermines deposits with resources of $\mathrm{Zn}$ and $\mathrm{Pb}$ of approximately $110 \mathrm{Mt}, 22 \mathrm{Mt}$, and $17 \mathrm{Mt}$, respectively [2-4]. In addition to $\mathrm{Zn}$ and $\mathrm{Pb}$, the province also contains a carbonate-hosted $\mathrm{Cu}$ - $\mathrm{Ag}$ resource mined out in the $70 \mathrm{~s}$, the Gortdrum deposit [5], and other underexplored deposits such as Tullacondra, Aherlow, and Ballyvergin. These deposits indicate that $\mathrm{Cu}$ and Ag were also available in the orefield for precipitating into mineral deposits, albeit the largest was Gortdrum with $3.8 \mathrm{Mt}$ at $1.19 \% \mathrm{Cu}$ and $25.1 \mathrm{~g} / \mathrm{t} \mathrm{Ag} \mathrm{[5].} \mathrm{The} \mathrm{limited} \mathrm{knowledge} \mathrm{about} \mathrm{these}$ $\mathrm{Cu}-\mathrm{Ag}$ occurrences hinders the assessment of the Irish Orefield as a potential province to be explored for these metals. Tullacondra, for example, was last and solely described in a seminal book chapter [6], and it was never revisited after the decades-long advances 
on Irish ore deposits research. Therefore, a better definition and characterization of the processes that govern mineralization at Tullacondra will aid exploration efforts targeting copper and help determine the potential for economic $\mathrm{Cu}$ mineralization associated with the Irish Orefield.

This study represents the first detailed assessment of the Tullacondra $\mathrm{Cu}-\mathrm{Ag}$ deposit geology, based on drill hole descriptions, whole-rock chemistry, petrography, SEM-EDS analyses, and semi-quantitative micro $X$-ray fluorescence element mapping across key textures. Our goal is to propose a genetic model for the Tullacondra deposit and frame its ore formation processes in the Irish orefield geology context.

\section{Geological Setting}

The basement of the Irish Orefield consists of Precambrian, Ordovician, and Silurian, metamorphic, metasedimentary, and metavolcanic rocks [7]. These sequences were deposited in the Iapetus Ocean and subsequently folded and faulted due to its closure during the Caledonian Orogeny in the Lower Paleozoic [7,8]. Sediments were unconformably deposited across this basement during the Upper Devonian and Lower Carboniferous due to an S-N marine transgression across Ireland [9] and formed the Munster Basin [10,11].

The Lower Carboniferous records a gradual transition from a continental to a shallow marine environment in which carbonate shelf sediments were deposited on top of the Munster Basin [7]. The lowermost Carboniferous units are composed of argillaceous limestone of the Navan Group, in the central Irish Midlands, and of the Lower Limestone Shale Formation (L.L.S.), in the south [12]. Above the L.L.S. lie the Ballymartin and Ballysteen formations $[3,7,13,14]$. The Ballymartin Formation consists of medium-grained argillaceous bioclastic limestone and calcareous shale. The Ballysteen Formation consists of locally dolomitized bioclastic limestone with low clay content. Overlying these units is the Waulsortian Limestone Formation, typically composed of dolomitized micritic limestone containing bioclasts $[10,13,15-17]$. The Waulsortian Limestone is considered to have been deposited at greater water depths ( 200 $\mathrm{m})$ than the Ballysteen Formation [15], between the photic and aphotic zones [16]. Associated with this extensional period of the Lower Carboniferous, mafic intrusions and volcaniclastic rocks are common, mainly in the southwest Irish Midlands in the Limerick area [5,18-20].

Deposition of the sedimentary sequences was controlled by synchronous ENE-trending faults, formed by reactivation of Caledonian basement faults [21,22]. These extensional fault zones developed relay ramps and damage zones enhancing permeability [23]. Later, during the Late Carboniferous and Early Permian, the Hercynian Orogeny led to inversion, causing ductile thickening, folding (buckling), thrusting, and fault reactivation [24,25].

Related to the Hercynian Orogeny is the formation of cleavage and veins. Axial plane cleavage is locally developed through the Munster Basin and the Lower Limestone Shale and varies from a slaty cleavage to a pressure solution cleavage depending on carbonate content $[21,25-30]$. The origin of cleavage has been considered between the pre- [24] and the end of the folding [31]. Posterior to the folding and the plane axial cleavage, major and minor-scale thrust faults developed, cutting prior folds and showing small displacement of no more than a hundred meters [24,25]. Successive perpendicular strike-slip faults with NS-trending strike were then formed [24].

\subsection{Carbonate-Hosted $\mathrm{Zn}-\mathrm{Pb}$ and $\mathrm{Cu}-\mathrm{Ag}$ Mineralization in Ireland}

The Irish Orefield is broadly recognized as the host of $\mathrm{Zn}-\mathrm{Pb}$ stratabound deposits, and the most economically important deposits are Lisheen, Silvermines, and Navan [12,32,33]. Their host rocks are the Waulsortion Limestone Formation and Navan Group. Lisheen and Silvermines are mostly hosted in the hanging wall of ENE-WSW normal faults $[4,12,34,35]$ within the Waulsortian micritic limestone, in association with dolomitic breccias [36,37]. On the other hand, the Navan deposit is hosted in basal argillaceous limestones of the Navan Group [4,12]. The main ore minerals are galena and sphalerite. Minor chalcopyrite, arsenopyrite, and tennantite occur within proximal feeder zones [12,32,36,38]. In summary, 
the formation of the Irish $\mathrm{Zn}-\mathrm{Pb}$ deposits occurred during an extension of the Irish platform in a rifting environment in the Lower Carboniferous when metal-bearing hydrothermal fluid percolated from the Paleozoic basement through normal faults. This metal-bearing fluid mixed with shallow marine bacteriogenic brines enriched in $\mathrm{H}_{2} \mathrm{~S}$ in the Lower Carboniferous rocks generated the mineralization $[4,12,19,23,32,39,40]$. The hydrothermal fluid has shown signatures of $\delta^{34} S>0 \%[4,9,12,39,40]$, while the predominant bacteriogenic brines signature contains negative values ( -26 to $-4 \%$ in Navan, for example, [4]).

Irish-type deposits are texturally like MVT deposits, but they show more genetic similarities with SEDEX deposits. Some of these similarities include an intracratonic formation with syn-sedimentary faults acting as conduits, similar metal and mineral zonation, evidence of thermohaline convection, and spatial and temporal association with magmatic activities [9]. However, whereas Irish Type deposits mineralize in a shallower marine environment, SEDEX deposits are formed in a deeper marine environment. Besides, bacteriogenic sulfate reduction (B.S.R.) is predominant in the Irish deposits, whereas thermochemical sulfate reduction (T.S.R.) dominates SEDEX deposits [9].

Various stratabound carbonate-hosted $\mathrm{Cu}-\mathrm{Ag}$ deposits are recorded in the southern Irish Midlands, hosted within the Lower Limestone Shale Formation [5,6,28,29,41-43]. These include the Carboniferous-hosted stratabound mineralization class defined by [28] and other deposits such as Tullacondra, Ballyvergin, Aherlow, and Gortdrum [44]. These carbonate-hosted $\mathrm{Cu}-\mathrm{Ag}$ deposits are characterized predominantly by chalcocite, bornite, chalcopyrite, arsenopyrite and tennantite, minor cinnabar, sphalerite, and galena, and their genesis compared to the Irish-type model remains unclear [6,41-43].

The geotectonic environment of these $\mathrm{Cu}-\mathrm{Ag}$ deposits is still unknown. Refs. [28,44] classified the $\mathrm{Cu}-\mathrm{Ag}$ deposits hosted in the Lower Limestone Shale as syn-compressional, formed during the Hercynian Orogeny, considering that they are hosted in Hercynian structures $[6,41,43]$. However, a recent Re-Os dating has shown that vein-hosted $\mathrm{Cu}$ deposits can be slightly older than the Irish $\mathrm{Zn}-\mathrm{Pb}$ deposits [45]. Furthermore, the spatial and temporal relationship between the mineralization and volcanic rocks from southern Irish Midlands suggests a genetic relation between magmatism and $\mathrm{Zn}-\mathrm{Pb} / \mathrm{Cu}-\mathrm{Ag}$ mineralization $[5,20]$. The magmatic activity has been considered a possible source of heat and water for the $\mathrm{Zn}-\mathrm{Pb}$ and $\mathrm{Cu}-\mathrm{Ag}$ mineralizing fluids $[5,6,19,20,46]$.

\subsection{The Tullacondra Deposit}

\subsubsection{Stratigraphy}

The stratigraphy of the Tullacondra compared with Navan, Lisheen, and Silvermines deposits and their localization in Ireland is depicted in Figure 1A,B. The base of the Tullacondra deposit consists of shales, sandstones, conglomerates, and red beds of the Old Red Sandstone (O.R.S.), the uppermost unit of the Munster Basin. The Lower Limestone Shale (L.L.S) overlies the O.R.S. and is the main host unit of the Tullacondra Cu-Ag deposit [6]. Ref [6] divided the L.L.S. at Tullacondra into seven sub-units from bottom to top: Lower and Upper Transition Series, Uniform Calcarenite, Lower Shaly Calcarenite, Oolitic Calcarenite, Silty Calcarenite and Upper Shaly Calcarenite.

Although the Transition Series belongs to the L.L.S. [6], we separated data from the Transition Series from the other L.L.S. sub-units because they show distinct petrological and chemical contrasts with them. The Lower and Upper Transition Series consist of $30 \mathrm{~m}$ of sandstone, conglomerate, and siltstone interbedded with calcareous sandstone, siltstone, and shale $[6,13]$. According to [6], at Tullacondra, the Lower Transition Series is mediumgrained (sand), whereas the Upper Transition Series is shale-dominated, both about $15 \mathrm{~m}$ thick. Ref [6] described a $30 \mathrm{~cm}$ thick horizon, termed the Hematite Marker at the contact between the Upper and Lower Transition Series, consisting of iron-oxide stained, rounded clasts. A similar marker was also reported by [13] in southwestern Ireland. 


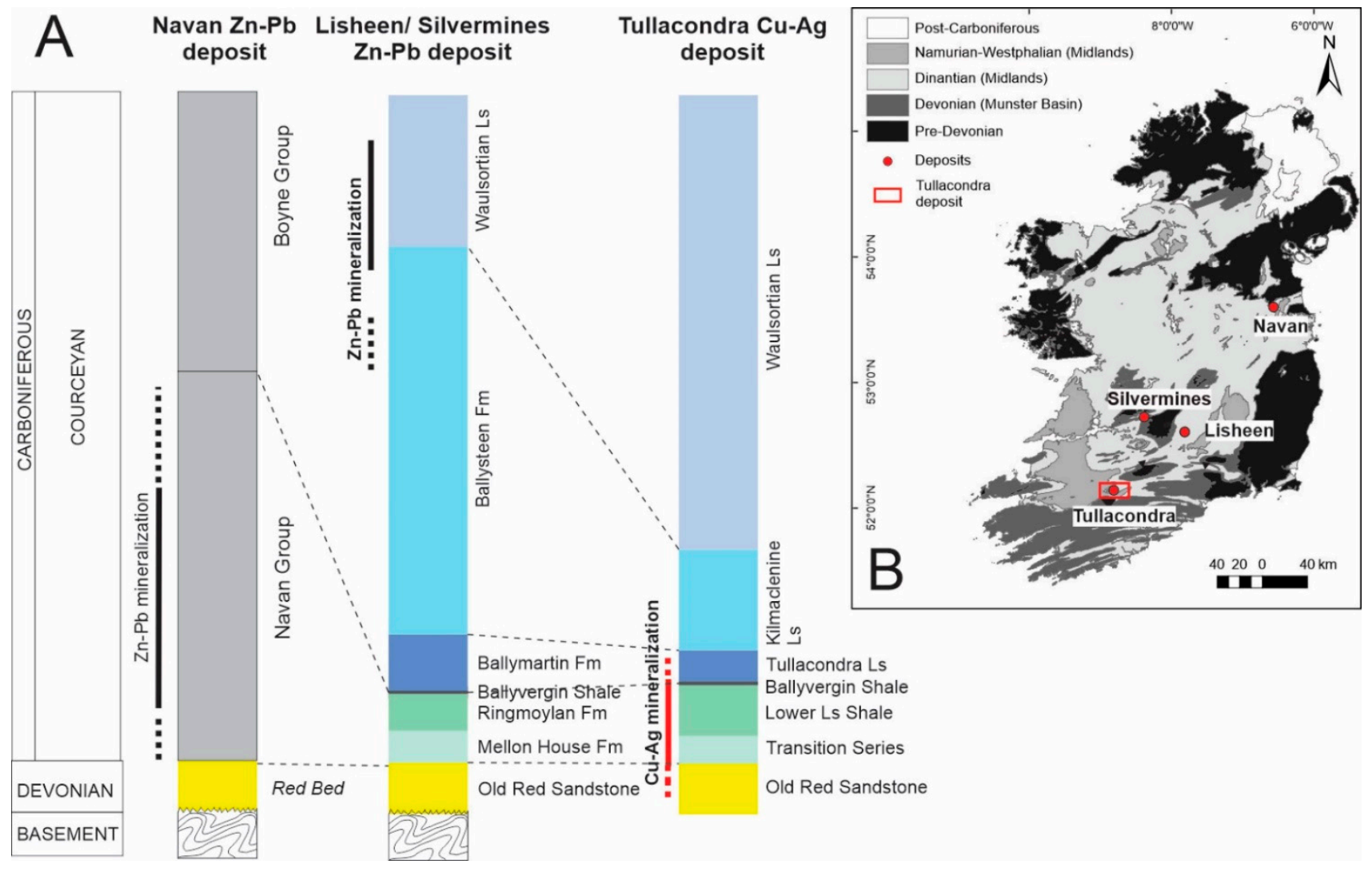

Figure 1. (A) Stratigraphic columns for the Navan, Lisheen, Silvermines, and Tullacondra deposits showing the lateral stratigraphic variation and the main host lithologies. The Waulsortian Limestone hosts the Lisheen and Silvermines deposits, the Navan Group hosts the Navan deposit, and the L.L.S hosts the Tullacondra deposit. Note also that the L.L.S. is laterally correlated with the Navan group. The Navan deposit column is based on [4,47-49]. The stratigraphic column for the Lisheen and Silvermines deposits is based on [2,3,13,36,47,49], and for the Tullacondra deposit on [6,10]. (B) Geological map of Ireland showing the main stratigraphic units and deposits. Note the localization of the Tullacondra in southern Ireland. Navan, Lisheen, and Silvermines are important sources of $\mathrm{Zn}-\mathrm{Pb}$. This map is based on data available by G.S.I. (see in Data Availability Statement).

The other five sub-units belonging to the L.L.S. are detailed in Table A1. Overlying the L.L.S. is a regional marker (the Ballyvergin Shale) which is $\sim 1 \mathrm{~m}$ thick at Tullacondra [6], the Tullacondra Limestone, and the Kilmaclenine Limestone, respectively $[3,7,13,14]$. The Tullacondra Limestone is $35 \mathrm{~m}$ thick at Tullacondra and comprises medium-grained crinoidal limestone with thin irregular shale partings and a siliceous base [6]. Above it, the Kilmaclenine Limestone is about $100 \mathrm{~m}$ thick at Tullacondra and comprises bioclastic limestone with low clay contents $[6,10]$.

The Waulsortian Limestone Formation is $450 \mathrm{~m}$ thick and is overlain by the Subulter Volcanic Group, composed of dark, thin-bedded pyroclastic rocks up to $100 \mathrm{~m}$ thick [6,10]. Thin dykes cutting drill holes are described in historical logging from Tullacondra. They were described as porphyritic rhyolitic dykes with a very fine-grained matrix, sometimes brecciated, cut by mineralized veins, and hosted within the mineralized L.L.S.

\subsubsection{Structural Geology}

The Tullacondra $\mathrm{Cu}-\mathrm{Ag}$ deposit is hosted on the northern flank of the Kilmaclenine anticline central area, an open fold with an ENE-WSW-trending hinge (Figure 2) [6]. This anticline is in the northern edge of the Hercynian deformation front (KMFZ) in the Transition zone $[6,24,50]$. Additionally, it has numerous smaller-scale minor folds and thrusts developed on its northern limb [6]. 
Hinge-parallel thrust faults cut the anticline. In the northern limb, the Kilmaclenine is cut by the Templemary Thrust and in the south by KMFZ [6,50]. According to [6], there is an EW-trending "proto-fault" controlling the Tullacondra mineralization. Intersecting these EW-trending faults are roughly N-S trending, steep faults [6].

\subsubsection{Mineralization}

Ref [6] defined two orebodies at Tullacondra: a stratabound silver-rich of 5 to $10 \mathrm{~m}$ thick located between the Upper and Lower Transition Series ( 0.6 Mt, $150 \mathrm{~g} / \mathrm{t} \mathrm{Ag}$, and $0.6 \% \mathrm{Cu}$ ) and another near-vertical Cu-rich of $370 \mathrm{~m}$ by $40 \mathrm{~m}$ and $120 \mathrm{~m}$ height (3.6 Mt, $0.7 \% \mathrm{Cu}$, and $27.5 \mathrm{~g} / \mathrm{t} \mathrm{Ag}$ ). The stratabound orebody consists predominantly of tennantite with minor bornite and chalcopyrite and specks of native $\mathrm{Ag}$, whereas the gangue minerals are calcite and quartz. The vertical orebody consists of bornite and chalcopyrite with traces of covellite, chalcocite, and neodigenite. The gangue minerals are calcite, dolomite, quartz, and sporadic barite. According to these authors, the ore minerals at Tullacondra are hosted in small veins ( $<0.25 \mathrm{~cm}$ in width), disseminated, and spots parallel to the bedding.
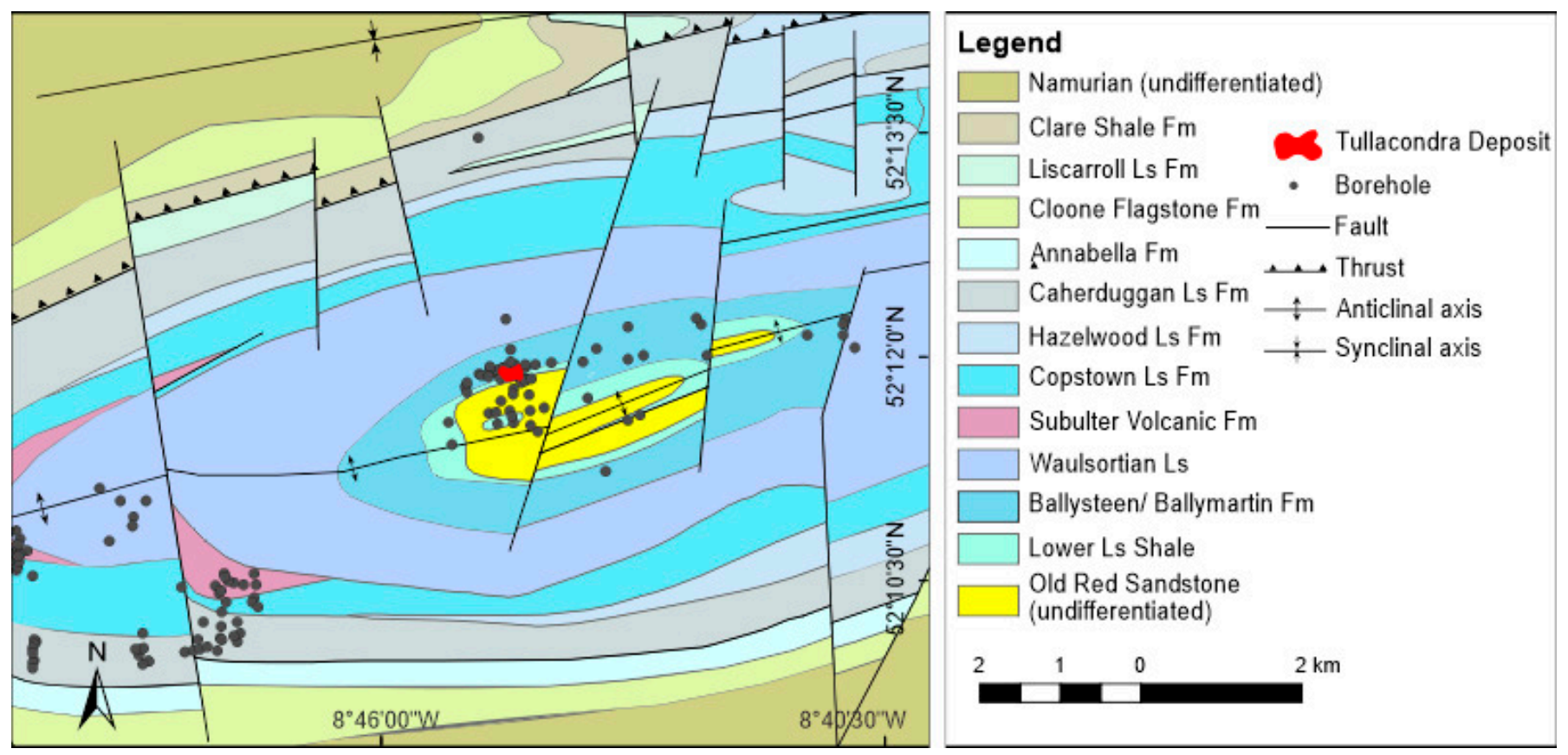

Figure 2. Geological map of the Kilmaclenine area showing the location of drill hole collars and the Tullacondra artisanal mine (red area). This map is based on data available by G.S.I (see in Data Availability Statement).

\section{Materials and Methods}

In this study, we used data compiled from about 30 drill holes (27 to $240 \mathrm{~m}$ depth) completed over 30 years in the Tullacondra area to model the geology of the deposit, the geometry of the mineralized zones, and the distribution of metals using Leapfrog Geo software. This legacy database includes drilling and assay data for $\mathrm{Cu}$ and Ag collected originally by the Munster Base Metals company from 1969 to 1986 and made available by the Geological Survey Ireland (G.S.I.). Additionally, this work had access to the historical drill core being stored by Diversified Asset Holdings Proprietary Limited, a company exploring the Tullacondra area at an early stage of this research. Forty-eight samples were collected from three drill holes forming an E.W. transect across the deposit to represent all mineralized zones and units of Tullacondra. Polished thin sections were produced from these samples for detailed petrography and textural determination. Mineral determination was complemented by semi-quantitative SEM-EDS analysis at the Laboratory of Mineral and Rock Analysis (LAMIR) of the Federal University of Paraná (UFPR), Brazil. The mineral abbreviation is based on [51]. 
To better detail the mineralogical and textural associations and geochemical variability across the deposit, we additionally employed micro-X-ray fluorescence imaging. Elemental maps of 14 sample offcuts representing the different lithologies and mineralizing styles of Tullacondra were produced by Edax Orbis micro-XRF instrument at the Center for Environmental Science and Technology (CEST), University of Notre Dame, U.S.A. Analytical parameters included a beam size of $30 \mu \mathrm{m}, 40 \mathrm{kV}$ accelerating voltage, and $300 \mu \mathrm{A}$ current $[52,53]$. Chemical maps were produced for the following elements: $\mathrm{Cu}, \mathrm{S}, \mathrm{Al}, \mathrm{Fe}$, $\mathrm{Ca}, \mathrm{P}, \mathrm{As}, \mathrm{K}, \mathrm{Mg}, \mathrm{Mn}, \mathrm{Si}, \mathrm{Ti}$, and $\mathrm{Zn}$, and ternary RGB images of $\mathrm{Ca}, \mathrm{Al}$, and $\mathrm{Cu}$ were subsequently generated using ImageJ software to discriminate between carbonates (Ca), silicates $(\mathrm{Al})$, and sulfides $(\mathrm{Cu})$.

Whole-rock analysis for major and trace element abundances was conducted to characterize the mineral and textural associations and geochemical variability across the deposit. Representative samples of ore types and lithologies were pulverized in a Widia pan mill at the LAMIR, and the pan was decontaminated by milling with quartz between each sample. Thirty-eight rock pulps were sent to the ALS Global laboratory for whole-rock analysis, where whole-rock assaying was performed following internal standards and analytical reproducibility procedures [54]. The pulps were fused into lithium tetraborate beads and were analyzed using different instruments: (1) ICP-AES using four acid digestion, and loss on ignition (L.O.I.) determined through the furnace (major elements and $\mathrm{Ag}, \mathrm{Cd}, \mathrm{Co}$, $\mathrm{Cu}, \mathrm{Li}, \mathrm{Mo}, \mathrm{Ni}, \mathrm{Pb}, \mathrm{Sc}$, and $\mathrm{Zn}$ ); (2) ICP-MS using acid digestions consisting of nitric, hydrochloric, and hydrofluoric acids (Ba, Ce, Cr, Cs, Dy, Er, Eu, Ga, Gd, Hf, Ho, La, Lu, $\mathrm{Nb}, \mathrm{Nd}, \mathrm{Pr}, \mathrm{Rb}, \mathrm{Sm}, \mathrm{Sn}, \mathrm{Sr}, \mathrm{Ta}, \mathrm{Tb}, \mathrm{Th}, \mathrm{Tm}, \mathrm{U}, \mathrm{V}, \mathrm{W}, \mathrm{Y}, \mathrm{Yb}$, and $\mathrm{Zr}$ ), and through aqua regia digestion (As, $\mathrm{Bi}, \mathrm{Hg}$, In, $\mathrm{Re}, \mathrm{Sb}, \mathrm{Sc}, \mathrm{Te}$, and $\mathrm{Tl}$ ); and finally, (3) the Leco furnace method was utilized for determination of total carbon and sulfur contents. The major element oxides $\left(\mathrm{Al}_{2} \mathrm{O}_{3}, \mathrm{SiO}_{2}, \mathrm{CaO}, \mathrm{MgO}, \mathrm{TiO}_{2}\right.$, and $\left.\mathrm{K}_{2} \mathrm{O}\right)$ are within the detection limits for method 1 . The lower and upper detection limits of the ore metals and sulfur are Ag (0.5-100 ppm), As (0.1-250 ppm), Cu (0.2-10,000 ppm), Pb (2-10,000 ppm), S (0.01-50\%), Sb (0.05-250 ppm), and $\mathrm{Zn}(2-10,000 \mathrm{ppm})$.

\section{Results}

\subsection{Geological Modelling}

The Tullacondra deposit is controlled by a steeply dipping, $250 \mathrm{~m}$ long, $\sim \mathrm{E}-\mathrm{W}$ trending fault referred to as the Tullacondra Fault (Figures 3 and 4) in this work. This structure was described by [6] as a monocline and proto-fault based on abrupt change of bedding dip from $15^{\circ}$ to $70^{\circ}$. Following the regional structural pattern, the Tullacondra Fault is truncated to the west and east by steep $\sim \mathrm{N}-\mathrm{S}$ trending faults named here Fault $\mathrm{A}$ and Fault $\mathrm{B}$, limiting the extension of the mineralized zone to the east and west.

The $\mathrm{Cu}$ and $\mathrm{Ag}$ grades reported in this chapter (4.1, Figures 3 and 4) are based on legacy assay data. The $\mathrm{Cu}$ and Ag grades vary spatially throughout the deposit, with the highest grades found between faults A and B (Figure 3). The mineralized area consists of an ore shell of $\mathrm{Cu}>0.2 \%$ and $\mathrm{Ag}>14 \mathrm{ppm}$. Our sample assay results from three drill holes from the western (M73-03), central (M73-11), and eastern (M73-19) areas of Tullacondra confirm legacy results and indicate further mineralogical variation throughout the deposit (Figure 4A,B).

The $\mathrm{Cu}-\mathrm{Ag}$ mineralization is characterized by two stratabound zones connected by a lower grade, near-vertical zone (Figure 4C-F) where disseminated, bedding-parallel, sulfide-bearing dissolution seams, and veins occur. The stratabound and near-vertical mineralized zones were defined by isograd contours of different cross-sections containing $\mathrm{Cu}(0.2-1.78 \%)$ and $\mathrm{Ag}(14-383 \mathrm{ppm})$. The data indicate two grade envelopes with different geochemical characteristics, zones 1 and 2, approximately $300 \mathrm{~m}$ length, $250 \mathrm{~m}$ width, and $10 \mathrm{~m}$ thickness. The vertical mineralized envelope (zone 3) forms a 370 by 240 more shell, with roughly $40 \mathrm{~m}$ of thickness [6] comprising the bulk of mineralization.

1. Mineralized zone 1 (Transition Series-hosted mineralized zone): the mineralized zone 1 is defined as a stratabound lens located between the Lower and Upper Transition 
Series. The main host rocks are calcareous sandstone and shale, and sandy calcarenite. It averages $150 \mathrm{ppm} \mathrm{Ag}$ and $0.6 \% \mathrm{Cu}$, according to [6], and hosts the highest $\mathrm{Ag}$ grades, mainly in the southern part of the deposit (up to $383 \mathrm{ppm} \mathrm{Ag}$ ). In this mineralized zone, the sulfides and sulfosalts (Figure 4) are zoned: (a) limited between the NS-trending faults consisting of tennantite-tetrahedrite-arsenopyrite-chalcopyrite $>$ bornite-chalcocite (Figure 4D,E) and (b) beyond the limit of these faults containing tennantite-tetrahedrite-arsenopyrite > chalcopyrite (Figure 4C,F);

2. Mineralized zone 2 (Lower Limestone Shale-hosted mineralized zone): This mineralized zone averages $30 \mathrm{ppm} \mathrm{Ag}$ and $0.7 \% \mathrm{Cu}$ and is hosted in the sub-units of the L.L.S. The main host rocks are calcareous shale or shaly calcarenite, but the mineralization is also hosted locally in massive calcarenite. In contrast to mineralized zone 1, the mineralized zone 2 lacks sulfide zonation and is characterized by chalcopyrite-bornite-chalcocite $>$ tennantite-tetrahedrite-arsenopyrite, and traces of pyrite;

3. Mineralized zone 3 (Near-vertical mineralized zone): This zone consists of $\mathrm{Cu}$ grades between 0.2 and $0.7 \%$ and $\mathrm{Ag}$ grades between 14 and $30 \mathrm{ppm}$ (Figure $4 \mathrm{D}, \mathrm{E}$ ). The ore mineralogy of this zone varies according to the host rocks. At the intersection of the mineralized zone 3 and the Transition Series, As minerals predominate. Where zone 3 intersects the L.L.S., $\mathrm{Cu}$ sulfides predominate, as observed in the mineralized zone 2.

The Ballyvergin Shale and Tullacondra Limestone are slightly mineralized (Figure 4D,E), but they are under-represented in this study with only five samples. The main host rocks are shale and calcarenite, respectively. Their mineralogy is characterized predominantly by chalcocite, bornite, chalcopyrite ( $>50 \%$ of the ore minerals), traces of pyrite; As minerals are absent.

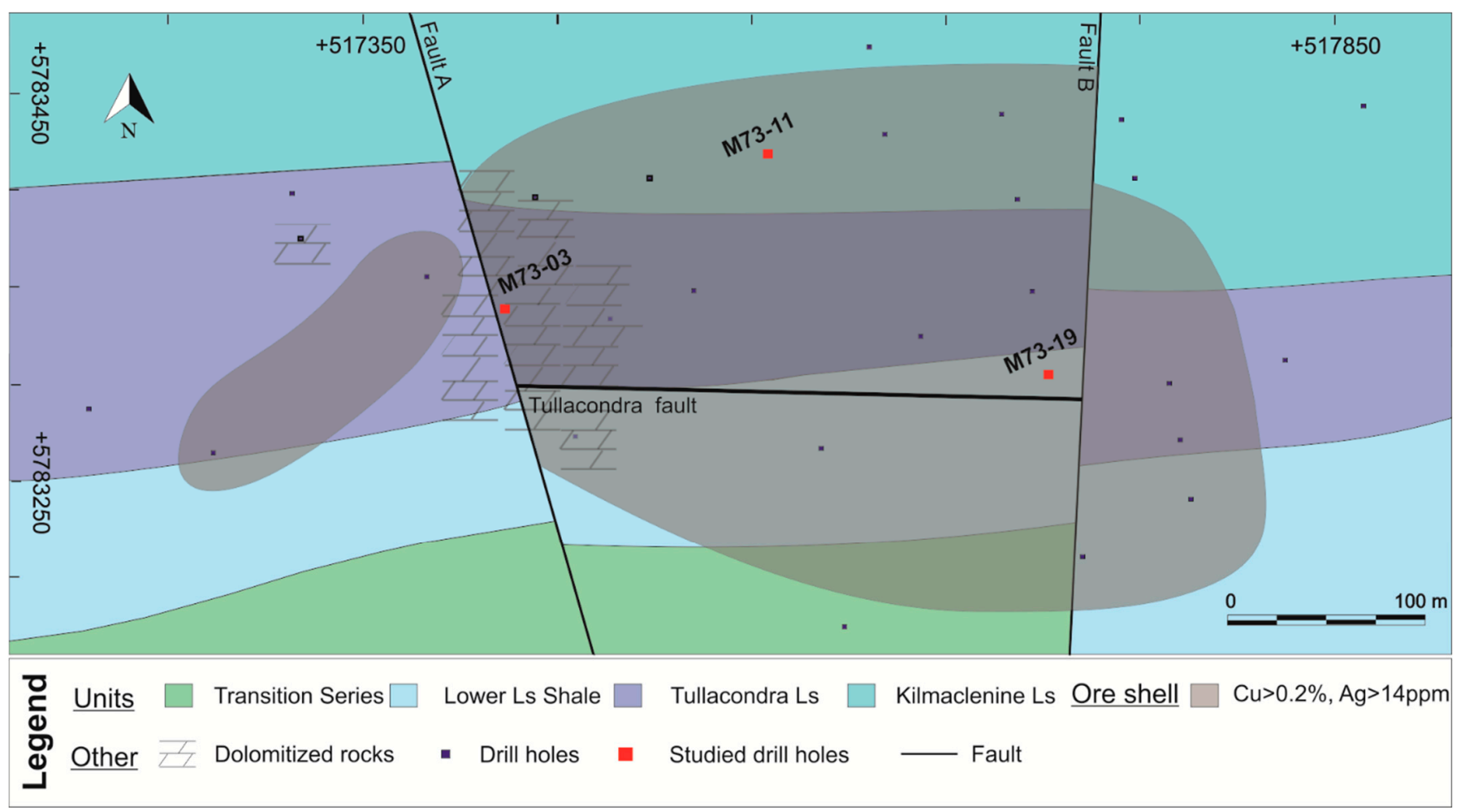

Figure 3. Local geological map of the Tullacondra deposit based on legacy data from drill hole logs and its main structural features (the Tullacondra, A, and B faults). The ore shell is represented in gray and corresponds to the mineralized zones with $\mathrm{Cu}>0.2 \%$ and $\mathrm{Ag}>14 \mathrm{ppm}$ to reflect natural breaks in grade values. Note the dolomitized area is roughly coincident with Fault A. 

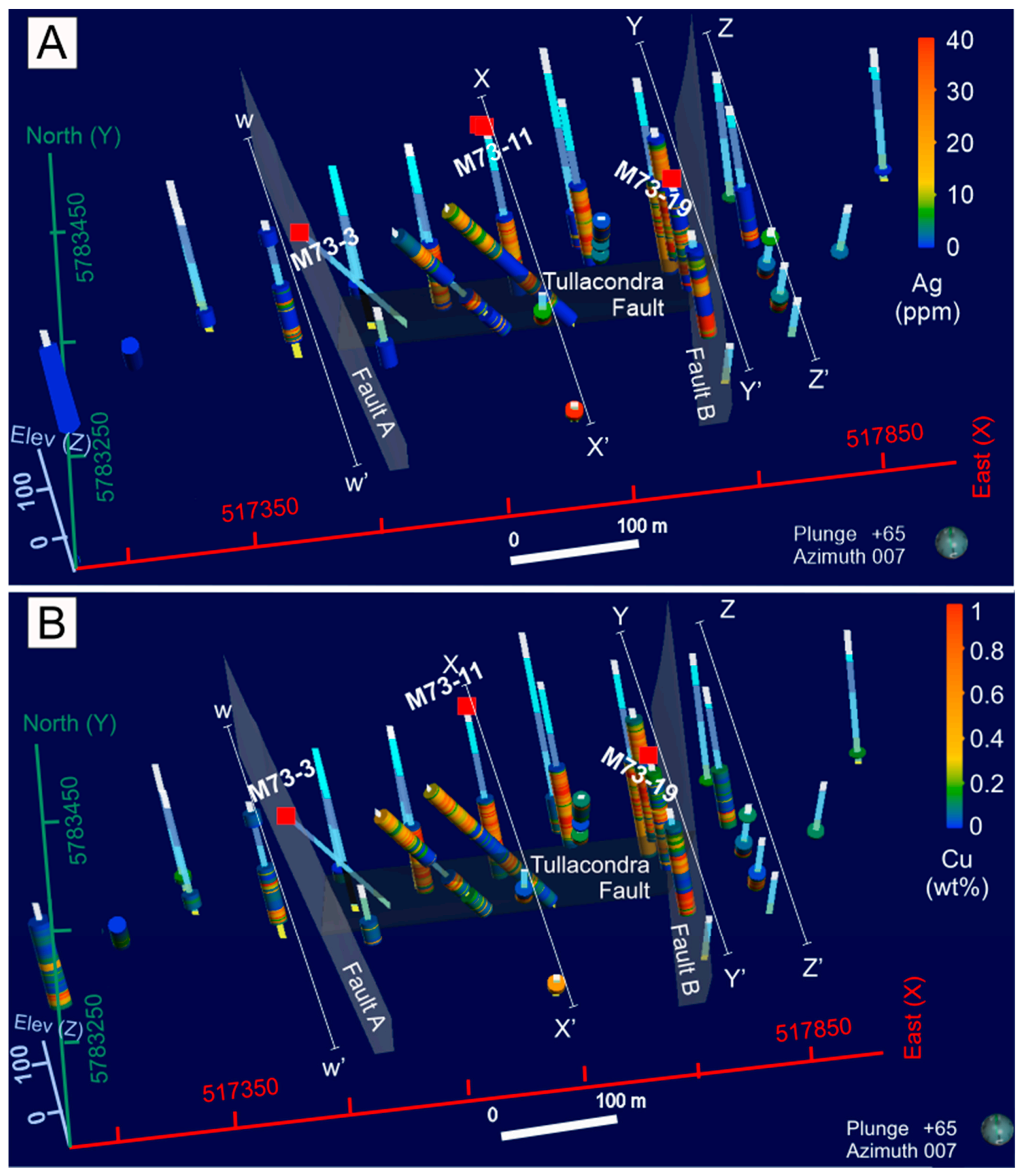

Figure 4. Cont. 

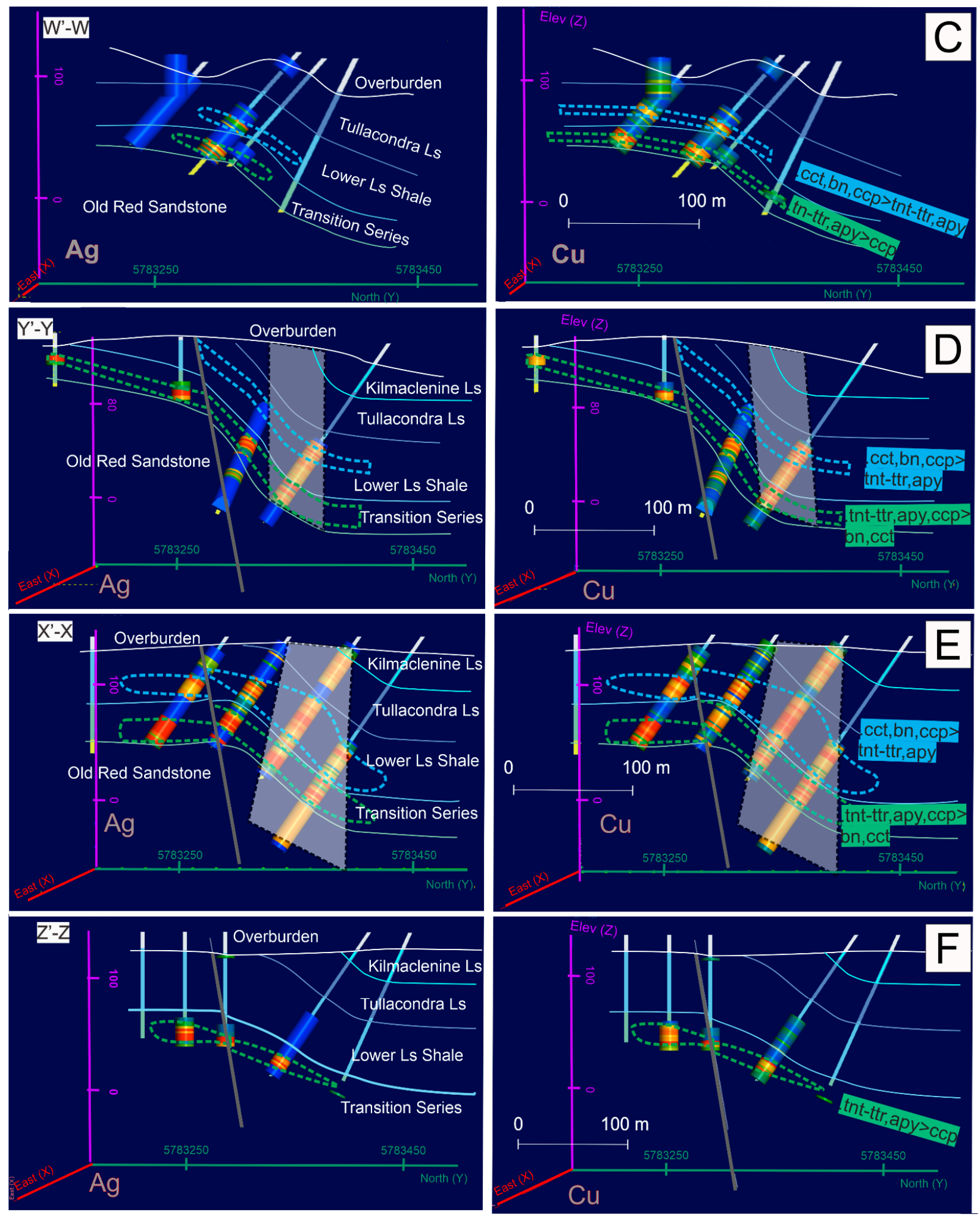

u Unknown $\square$ Overburden $\square$ Kilmaclenine Ls

$\square$ Transition Series

$\square$ Old Red Sandstone

@- Mineralized zone 1 i...; Mineralized zone 2

Tineralized zone 3 (Near-vertical mineralized zone)

Figure 4. Spatial distribution of core logging, faults, $\mathrm{Ag}(\mathbf{A})$, and $\mathrm{Cu}(\mathbf{B})$ assay data. Figure $4 \mathrm{C}-\mathrm{F}$ are cross-sections of the Tullacondra deposit (looking west) showing the localization of the $\mathrm{Cu}(>0.2 \%)$ and $\mathrm{Ag}(>14 \mathrm{ppm})$ mineralization determined 
by our visual estimation. (C) Cross-section $W-W^{\prime}$ located in the western part of the deposit. (D,E) Cross sections $X-X^{\prime}$ and Y-Y' located in the center of the deposit. (F) Cross-section Z-Z' shows the eastern deposit. Note the occurrence of two stratabound and a near-vertical mineralized zone. The dominant sulfide and sulfosalts mineralogy in each mineralized zone is also shown. The stratabound mineralized zone 1 consists of tennantite-tetrahedrite-arsenopyrite-chalcopyrite $>$ chalcocite-bornite. Note that outward the NS-trending faults (Figure 4C,F), chalcocite, and bornite are absent. The stratabound mineralized zone 2 contains chalcocite-bornite-chalcopyrite $>$ tennantite-tetrahedrite-arsenopyrite. The nearvertical mineralized zone intersects the other two mineralized zones.

\subsection{Petrography}

The main pre-ore minerals are calcite, quartz, and phyllosilicates with trace feldspar, rutile, zircon, monazite, barite, hematite, and ilmenite. Calcite occurs as coarse- to mediumgrained bioclasts, oolites, sparite, micritic or microsparitic cement, and coarse-grained sparitic veins. After calcite, quartz and phyllosilicates are the most common minerals recorded in the Tullacondra deposit. They are medium-grained and occur throughout the deposit. Whereas quartz grains are sub-rounded, micas are subhedral to euhedral and bedding-parallel. Traces of potassium feldspar, barite, monazite, and zircon also occur as sub-rounded medium- to fine-grained crystals in sandstone from the O.R.S. and the Transition Series. Hematite and ilmenite are characterized by medium- to fine-grained crystals restricted in the Red Beds (uppermost part of the O.R.S.). They are elongated, bedding-parallel crystals together with medium-grained potassic mica and ilmenite.

Ferroan dolomite is restricted to samples from the western area of Tullacondra. It occurs either as fine- to medium-grained anhedral dolomite replacing bioclasts, calcitic cement, or has completely replaced calcarenite in medium-grained, euhedral-subhedral crystals (Figure 5A) and as medium-grained euhedral-subhedral crystals in sparitic pink veins.

Fine- to medium-grained pyrite, $\mathrm{Cu}$, and As sulfides, and sulfosalts are the main ore minerals. Minor supergene minerals such as malachite, hematite, and covellite are also recorded in the Tullacondra Limestone, but they are outside the scope of this study. Pyrite is characterized by fine- to medium-grained subhedral and euhedral disseminated grains, replacing calcitic bioclasts or by grains formed along serrated stylolite surfaces in calcarenite (Figure 5B). Our petrography analysis shows pyrite hosted mostly in unmineralized samples (barren samples). The micro X-ray fluorescence analyses show that pyrite contains elevated $\mathrm{As}$ and $\mathrm{Pb}$ and is not associated with other sulfides.

Bornite and chalcopyrite, and minor chalcocite, mark the first generation of $\mathrm{Cu}$ mineralization. They are fine- to medium-grained, anhedral, usually clustered (Figure 5C), and exsolution lamellae of chalcopyrite occur within bornite (Figure 5D). They are described as locally associated with fine to medium-grained chlorite and apatite (Figure 5E). Although these minerals occur throughout the three mineralized zones, they are more abundant in mineralized zones 2 and 3 but subordinate south of the Tullacondra Fault and beyond the A and B faults.

Tennantite and a second generation of chalcopyrite, and arsenopyrite, are fine- to medium-grained subhedral to anhedral phases. SEM-EDS and micro XRF analysis show that tennantite predominates over tetrahedrite. They overlap Cu sulfides (Figure 5F,G) and are often rimmed by subhedral quartz and chalcedony (Figure $5 \mathrm{H}$ ). Chalcopyrite and traces of arsenopyrite are the only ore minerals found in dolomitized calcarenite (Figure 5I). SEM-EDS analyses show that vein-hosted tennantite contains minor amounts of $\mathrm{Ni}, \mathrm{Co}$, and Bi close to the Tullacondra fault. 

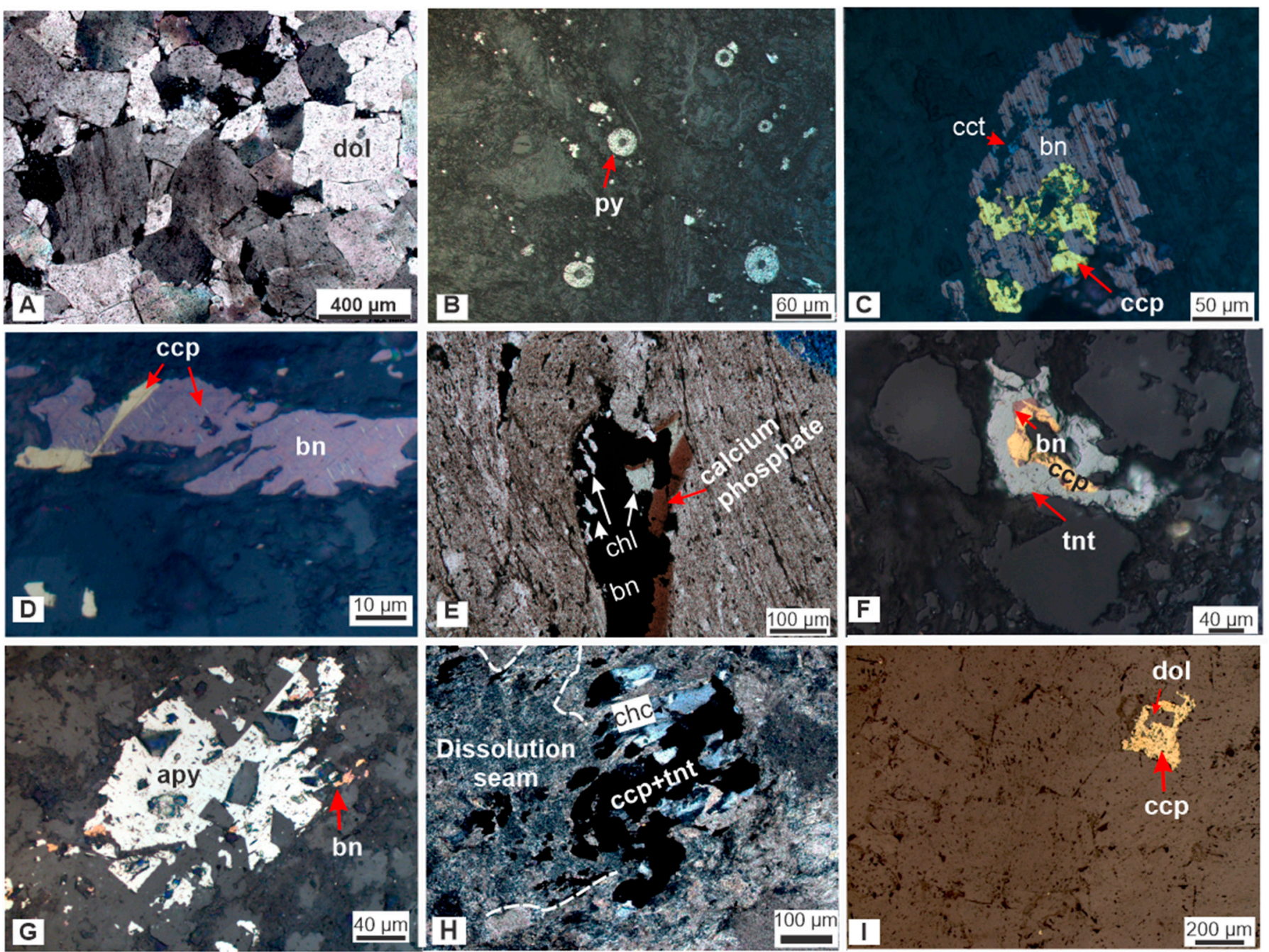

Figure 5. Photomicrographs illustrating the main sulfides and sulfosalts and their relationship with other minerals. (A) Euhedral to subhedral dolomite. (B) Pyrite (py) replacing bioclasts. (C) Chalcocite (cct), bornite (bn), and chalcopyrite (ccp) clustered. (D) Lamellae of chalcopyrite within bornite. (E) Bornite with inclusions of chlorite (chl) and calcium phosphate (F) Tennantite (tnt) overprinting chalcopyrite and bornite. (G) Arsenopyrite (apy) overprinting bornite. (H) Chalcopyrite and tennantite with chalcedony (chc) hosted in dissolution seam. (I) Chalcopyrite encircling dolomite (dol).

\subsection{Sulfides and Sulfosalts Texture}

The Tullacondra deposit contains a limited variety of sulfides and sulfosalts textures (Table A2), which have been divided into: (1) disseminated and bedding-parallel; (2) dissolution seam-hosted; (3) vein-hosted. These textures host $\mathrm{Cu}$ and As minerals and occur in the three mineralized zones. However, disseminated, bedding-parallel, and dissolution seam-hosted sulfides and sulfosalts occur predominantly in the mineralized zone 1 and 2 . On the other hand, the vein-hosted ore minerals are more common when compared to the other textures in the vertical mineralized zone 3 between the mineralized zones 1 and 2 .

1. Disseminated and bedding-parallel sulfides and sulfosalts: Disseminated and beddingparallel sulfides are pervasive throughout the Tullacondra deposit and represent the main ore texture, characterized by fine- to medium-grained chalcocite, bornite, chalcopyrite, and pyrite. Disseminated textures are observed within (dolomitized) calcarenite and sandstone, and $\mathrm{Cu}$ and As sulfide and sulfosalts replace bioclasts and oolites and infill pores (Figure 6A-C); in contrast, bedding-parallel sulfides are associated with shaly units in which sulfides occur along bedding planes (Figure 6D-F). Both textures contain sulfide and sulfosalts overprinting carbonate grains or cement. 
Disseminated and bedding-parallel textures are also common and spatially associated with zones of dissolution seams-hosted sulfides and sulfosalts.

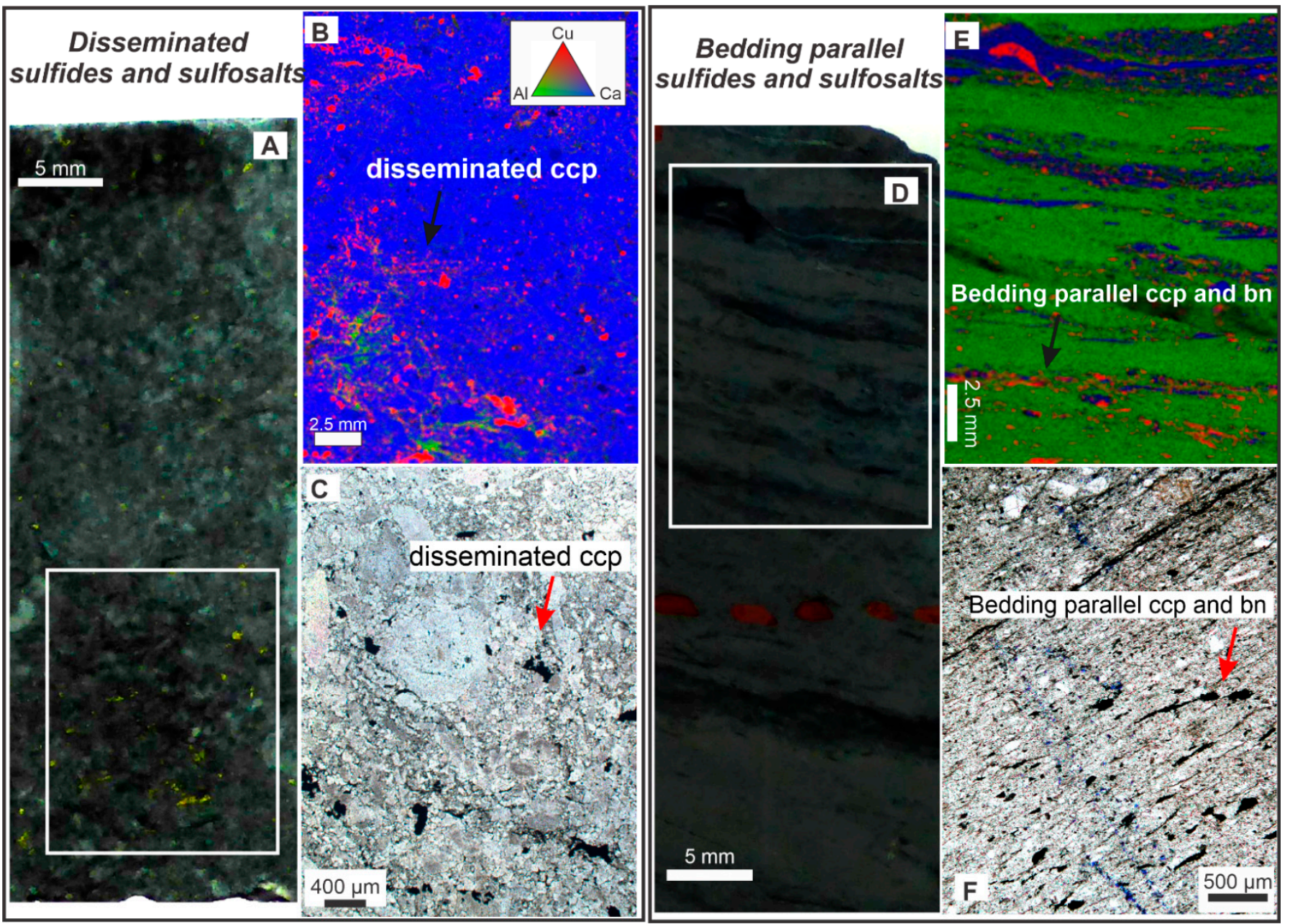

Figure 6. (A,D) Hand sample images; (B,E) Semi-quantitative chemical maps obtained by micro X-ray fluorescence analysis indicating the variation in the abundances of $\mathbf{C u}, \mathbf{C a}$, and $\mathrm{Al}$, and $(\mathbf{C}, \mathbf{F})$ their respective photomicrographs. The figures (A-C) show disseminated sulfide and sulfosalts, while the figures (D-F) show bedding-parallel texture.

2. Dissolution seam-hosted sulfides and sulfosalts: Dissolution seam-hosted sulfides and sulfosalts are in general more sulfide/sulfosalts-rich (up to $5 \%$ ) compared to disseminated and bedding-parallel textures (Table A2). Dissolution surfaces occur closely spaced in shaly calcarenite and shale and spaced at 1 to $5 \mathrm{~cm}$ in calcarenite and calcareous sandstone. They are mostly mineralized to barren, bedding-parallel anastomosing dissolution seams (non-serrated) and subordinate barren seams (serrated). These seams are usually up to $1 \mathrm{~cm}$ thick (thicker in some cases) and are filled by very fine- to fine-grained quartz, phyllosilicates, traces of very fine-grained oxides, and organic matter (bitumen). Additionally, they are continuous bifurcate around, not cutting clasts, or cut calcite clasts (Figure 7A-C). Some calcite clasts are flattened and locally show slight asymmetry. The medium-grained mica is often within the seams and shows a preferred bedding-parallel orientation (Figure 7D). Dissolution seams can evolve to incipient breccias characterized by fine-grained matrix surrounding calcitic clasts and, in the western area, surrounding partially dolomitized clasts (Figure 7E,F). These clasts are fine- to coarse-grained and subrounded to subangular with sharp to irregular contact with the matrix. Ore minerals commonly occur along dissolution seams and within breccias on the boundaries between calcitic clasts and matrix. 

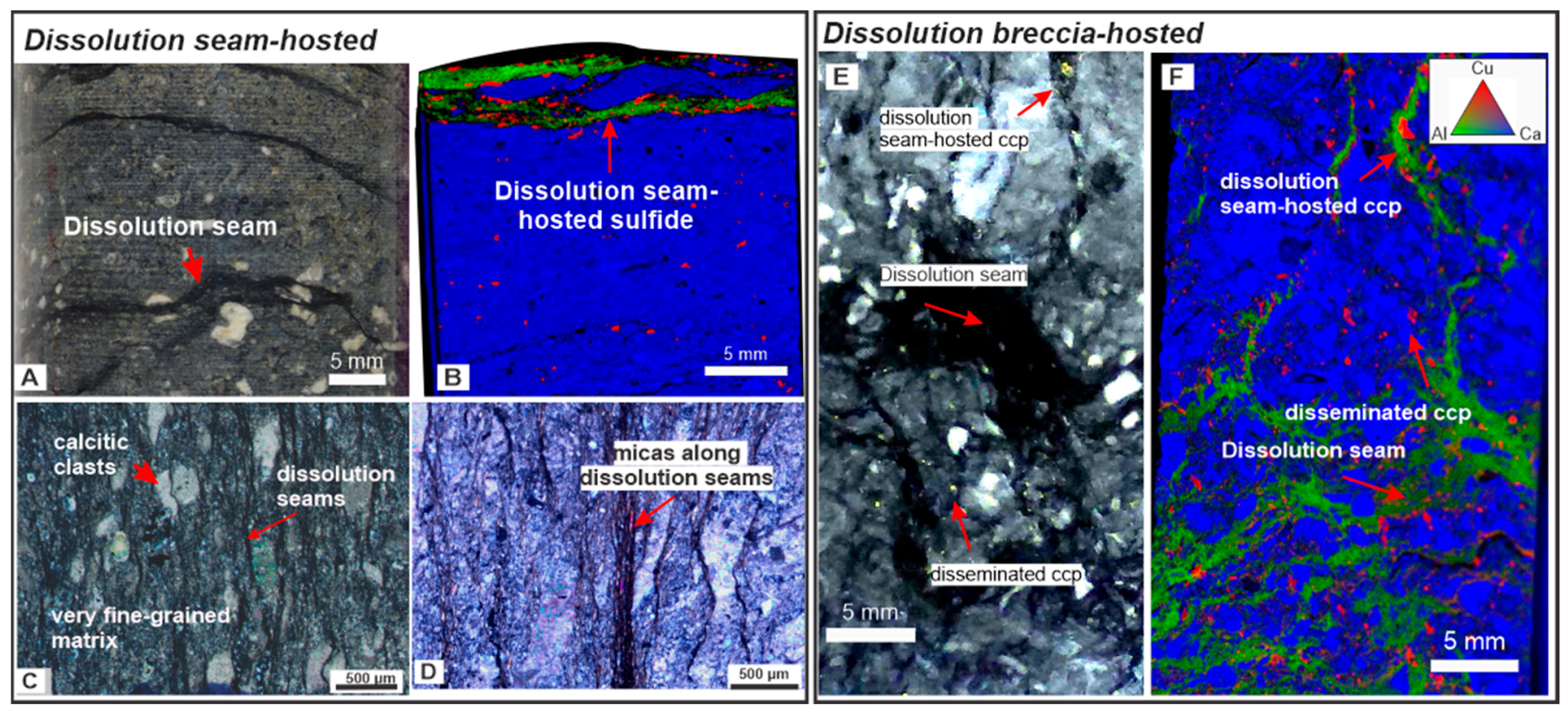

Figure 7. (A) Hand sample images showing dissolution seams. Note that the seams are cutting the calcite clasts. (B) Semi-quantitative chemical maps obtained by micro-X-ray fluorescence ( $\mu$ FRX). The figures show dissolution seam-hosted sulfides. (C) Calcite clasts cut by dissolution seams in a very fine-grained matrix. (D) Very-fine grained matrix with mica along bedding-parallel dissolution seams. (E) Hand sample images and (F) Semi-quantitative chemical maps by $\mu F R X$ showing dissolution breccia hosted sulfide and sulfosalts.

3. Vein-hosted: Vein-hosted sulfides and sulfosalts are characterized by anhedral, coarseto fine-grained ore minerals within medium-grained sparitic calcite, ferroan dolomite, and quartz veins that are approximately up to $1 \mathrm{~cm}$ thick, although they can be locally thicker (Figure 8A-D). These veins cut through the other ore textures (disseminated, bedding-parallel, and dissolution-hosted ore minerals) but contain the same ore mineral and gangue assemblage as the mineralized host rock. The vein-hosted sulfides occur mainly along the vein wall, but they also form disseminations within the veins. Regarding their orientation, veins are usually steeply dipping bedding-oblique, and stockwork veins are common close to the Tullacondra Fault, and dolomite veins are usually parallel to calcite veins. Ore minerals within veins and close to dissolution seams usually develop a parallel orientation to the seams. 


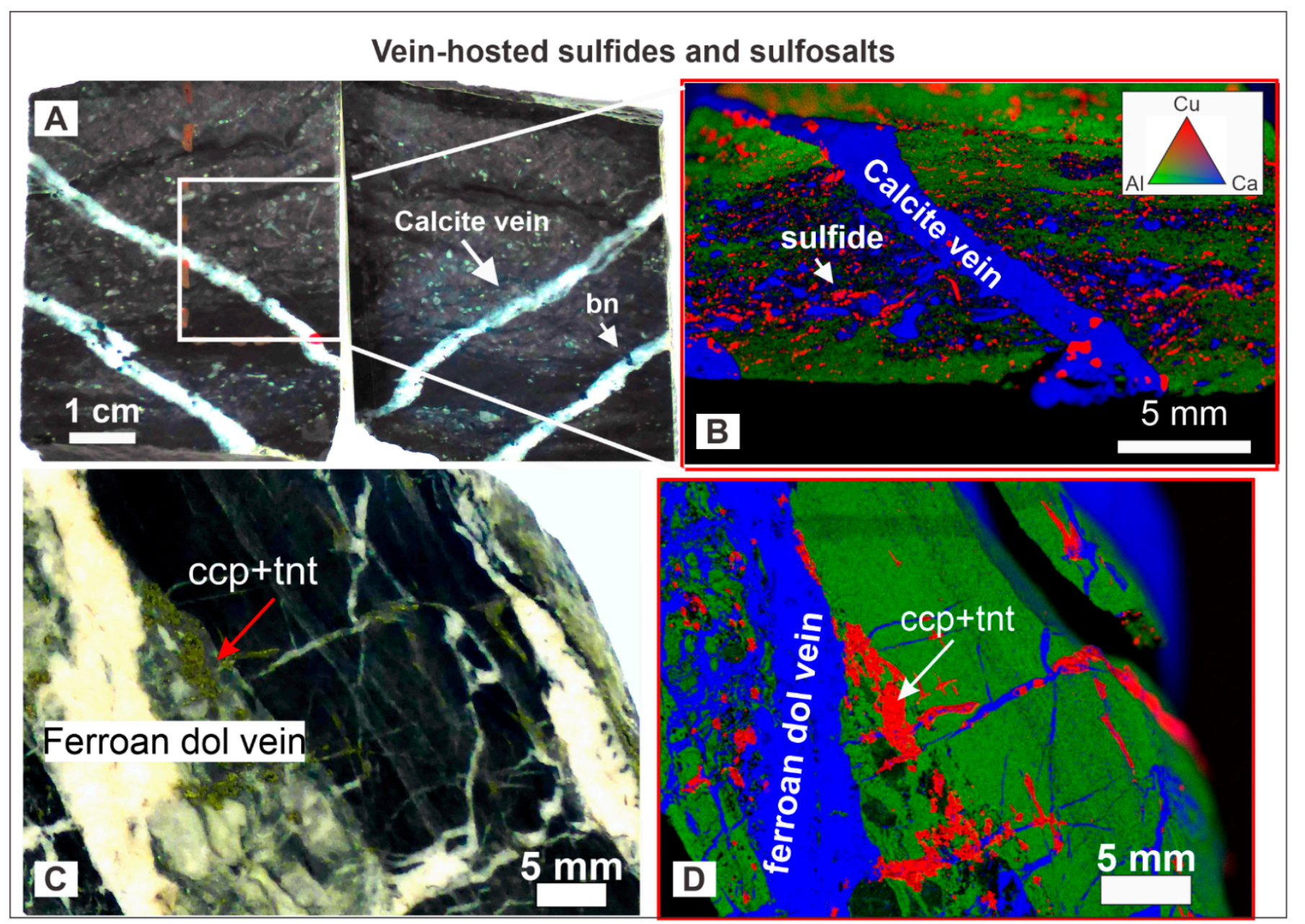

Figure 8. (A,C) Hand sample images and (B,D) Semi-quantitative chemical maps by $\mu$ FRX analysis showing vein-hosted ore minerals.

\subsection{Geochemistry}

Assay data (Table A3 and Table S1 in Supplementary Materials) reveal some trends and correlations between major elements $\left(\mathrm{SiO}_{2}, \mathrm{CaO}\right.$, and $\left.\mathrm{MgO}\right)$ and ore-related metals $\left(\mathrm{Cu}, \mathrm{Ag}\right.$, As, and Sb). Calcium oxide increases (0.39-51.6\%) upward while $\mathrm{SiO}_{2}(3.83-90.5 \%)$ shows the highest content in the basal units-the Transition Series and O.R.S. However, $\mathrm{SiO}_{2}$ content fluctuates along the stratigraphic column (average $20 \%$, but up to $60 \%$ ) throughout the L.L.S. (Figure 9). Magnesium oxide is generally lower than $5 \%$ in our dataset, except for samples from the western area, where they can reach between 17 and $19 \%$ (Figure 9A). Higher $\mathrm{Cu}$ content coincides with several peaks of $\mathrm{SiO}_{2}$ in upper units around the Ballyvergin Shale and some intervals of the L.L.S. and Transition Series from the drill hole M73-03 (samples 119, 143, 233, 318, 328, 347, and 393; Figure 9A), M73-11 (samples 296, 422 and 450; Figure 9B) and M73-19 (samples 249 and 257; Figure 9C). On the other hand, peaks of $\mathrm{CaO}$ and $\mathrm{MgO}$ lack any strong correlation with $\mathrm{Cu}$, although $\mathrm{Cu}$ is abundant in some samples with low $\mathrm{SiO}_{2}$ and higher $\mathrm{CaO}$ (samples 39, 69, 196, and 203 from the drill hole M73-03, Figure 9A; sample 347 from the drill hole M73-11, Figure 9B; and 133 from the drill hole M73-19, Figure 9C).

Correlations between $\mathrm{Cu}$ and other ore-related metals depend on the host units. Copper shows a positive correlation with Ag, except for the western area of the deposit (M73-03, Figure 9A). This area also contains the lowest $\mathrm{Ag}$ concentration (up to $40 \mathrm{ppm}$ ), while the central and eastern areas of Tullacondra have more than $100 \mathrm{ppm}$ of Ag. Arsenic and Sb are strongly correlated and show a positive correlation with copper in the Transition Series. 
The metal abundances shown in Figure 9A-C indicate a correlation with their orerelated minerals and vary according to the units. Chalcocite and bornite are major ore minerals in the L.L.S., while chalcopyrite occurs throughout all host units. The L.L.S. contains high grades of $\mathrm{Cu}$ and Ag. Tennantite and tetrahedrite occur mostly in the Transition Series, where the highest As and Sb concentrations are recorded. Arsenopyrite and pyrite are minor ore minerals and accordingly occur where the concentration of As is elevated. A pyrite-bearing sample from the upper L.L.S. (M73-11-290, Figure 9B) shows elevated $\mathrm{As}$ while $\mathrm{Sb}$ is below the detection limit. Pyrite was observed locally in the uppermost unit Tullacondra Limestone and Transition Series. Arsenopyrite in the L.L.S. and the Transition Series is accompanied, as expected, by elevated As.

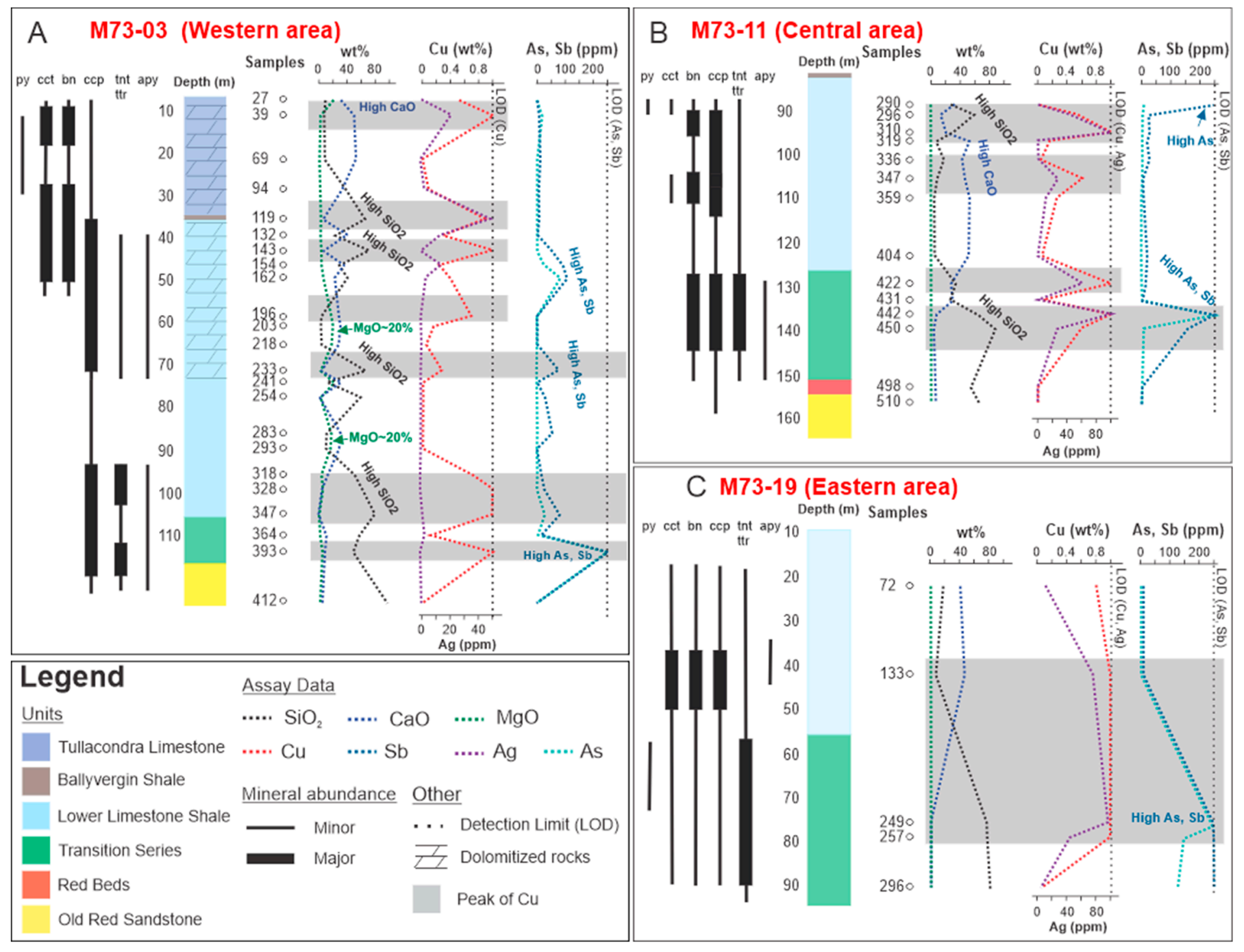

Figure 9. Assay data and mineral abundance from sampled drill cores from: (A) the western area, (B) the central area, and (C) the eastern area. Bore hole locations are depicted in Figures 4 and 5. Note the variation of the main ore minerals pyrite (py), chalcocite (cct), bornite (bn), chalcopyrite (ccp), tennantite (tnt), tetrahedrite (ttr), and arsenopyrite (apy), and of main elements $\left(\mathrm{SiO}_{2}, \mathrm{CaO}\right.$, and $\left.\mathrm{MgO}\right)$ and ore-related metals $(\mathrm{Cu}, \mathrm{Ag}, \mathrm{As}$, and $\mathrm{Sb})$. Peaks of $\mathrm{Cu}$ content are highlighted/shaded in grey.

The geochemical data is also depicted as bivariate plots (Figure 10) to allow further chemical comparison between stratigraphical units and mineralization types/zones. The values of $\mathrm{Al}_{2} \mathrm{O}_{3}(0.27-20.4 \%), \mathrm{K}_{2} \mathrm{O}(0.1-5.89 \%)$, and $\mathrm{TiO}_{2}(0.01-0.92 \%)$ show a strong positive correlation and a slightly weaker positive correlation with $\mathrm{SiO}_{2}$. Magnesium oxide shows medium (1 to $8 \%$ ) and high (17.05 to $19.55 \%$ ) concentrations in the western area 
but low values $(<1 \%)$ in the central and eastern areas. Copper and $\mathrm{Ag}$ are also variably concentrated depending on the area of the deposit. In the central and eastern areas, they are positively correlated with each other and with $\mathrm{S}$ but, in the western area, $\mathrm{Ag}$ is nearly absent. A correlation between $\mathrm{Ag}$ and $\mathrm{As}$ and $\mathrm{Sb}$ is not clear. The bivariate plot of $\mathrm{Ag}$ vs. As $+\mathrm{Sb}$ shows that the L.L.S.-hosted mineralized zone contains low As and $\mathrm{Sb}$ grades (Figure 9). Other base metals generally associated with $\mathrm{Sb}$, As are not relevant in our sample set (Table A3 and Table S1 in Supplementary Materials).
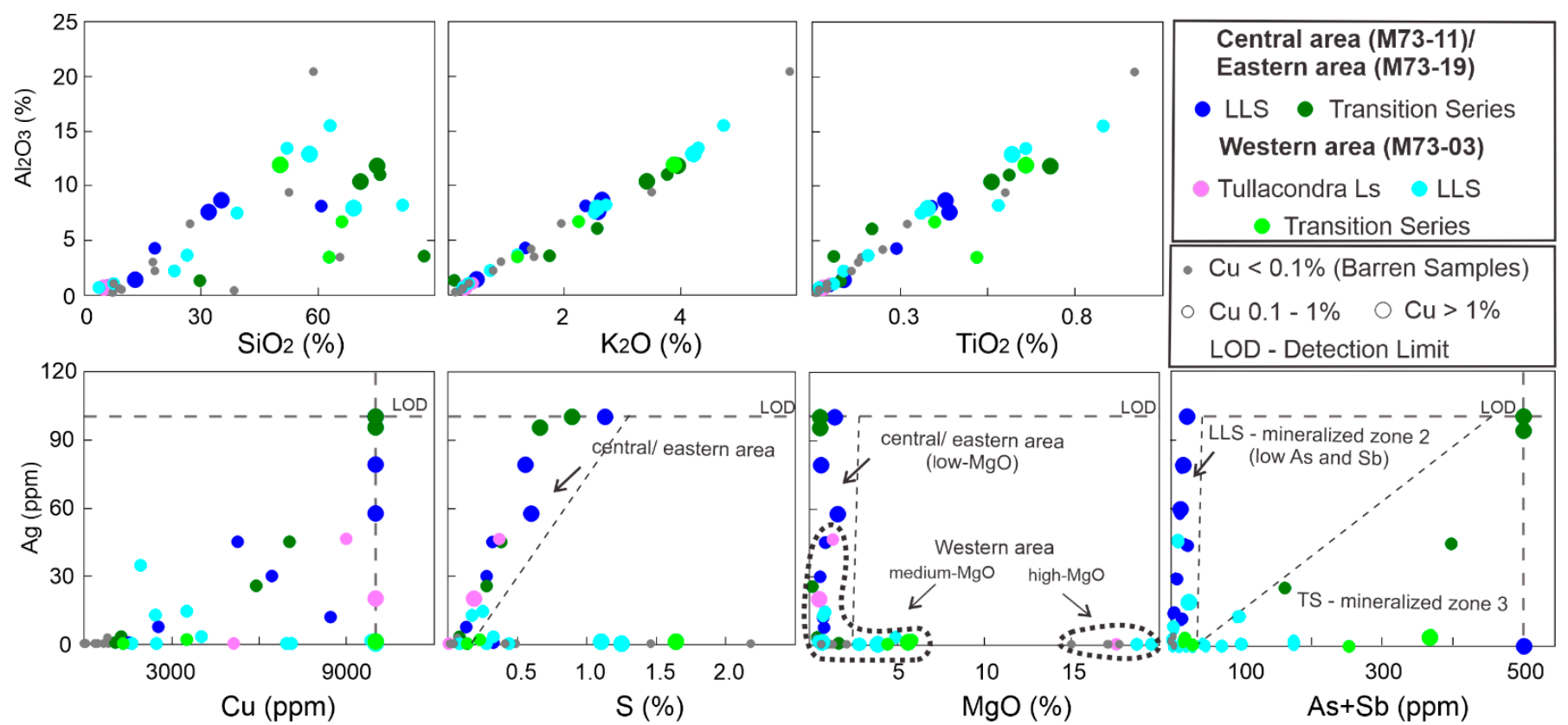

Figure 10. Bivariate plots showing the positive correlation between $\mathrm{Al}_{2} \mathrm{O}_{3}$ and other major elements $\left(\mathrm{SiO}_{2}, \mathrm{~K}_{2} \mathrm{O}_{,} \mathrm{Al}_{2} \mathrm{O}_{3}\right.$, $\mathrm{TiO}_{2}$ ) and $\mathrm{Ag}$ versus $\mathrm{Cu}, \mathrm{S}, \mathrm{MgO}$, and $\mathrm{As}+\mathrm{Sb}$ in different mineralized and barren host rocks (from the western, central, and eastern areas).

\section{Discussion}

\subsection{Host Rocks and Post-Depositional Events}

The mineralogical and geochemical data are consistent with the interpretation that the Tullacondra mineralized zones are hosted in rocks deposited during a marine transgression [55]. Host rocks show high contents of $\mathrm{SiO}_{2}$ at the base of the sequence, consistent with siliciclastic-dominant sediments, which decrease up sequence along with an increase in the $\mathrm{CaO}$ abundance due to the progressive dominance of limestones and marls (Figure 9).

Dolomitization seems to be unrelated to mineralization in Tullacondra. The samples investigated suggest that pervasive dolomitization is limited to the western deposit (Figure 3) where $\mathrm{MgO}$ wt.\% and ore-related metals lack any correlation (Figures 9 and 10). Dolomite at Tullacondra occurs either as pre-mineralization anhedral to euhedral dolomite in host rocks or post-mineralization ferroan dolomite in veins (Figure 5A,I). Pre-mineralization dolomite can be engulfed by second-generation chalcopyrite and indicate a post-dating relationship for the mineralization (Figure 5I). Barren dolomite veins, on the other hand, cut mineralization and show their late-ore stage origin. Additionally, dolomitized samples contain the lowest Ag grades, with most of them below the detection limit $(<0.5 \mathrm{ppm})$, implying a lack of correlation between dolomite and Ag (Figure 9).

Unlike pervasive dolomitization, dissolution seams containing localized dolomite are important in hosting ore minerals, as demonstrated by a higher concentration of ore minerals hosted in dissolution seams than other textures. However, the barren nature of most dissolution seams in various parts of the deposit suggests that a diagenetic fluid flow process responsible for their genesis might belong to the pre-ore stage and that this fluid 
was low metal content. The occurrence of organic matter within dissolution seams could have acted as an additional trap for mineralization. The development of little (burial or tectonic) deformation and mineralized dissolution breccias associated with dissolution seams fits better with a pre-ore stage.

The development of these pre-ore stage seams differs from solution cleavage recorded in the Munster basin and formed during the Hercynian deformation [21,25-30]. Although dissolution seams at Tullacondra and typical solution cleavage are similarly spaced depending on the host lithology, we have no evidence that the mineralized dissolution seams at Tullacondra are plane axial like the typical solution cleavage. On the contrary, our dissolution seams are predominantly parallel to sub-parallel to bedding.

Thus, we interpret that the seams were formed by a pre-ore process related to diagenesis and burial, associated with the dissolution of calcite along surfaces that were largely bedding parallel. These structures were enriched in phyllosilicates and organic matter and were variably dolomitized. Incipient brecciation along dissolution seams at Tullacondra seems to locally evolve into breccias with limestone clasts within a quartz-sericite matrix (Figure 7A-F).

Dissolution seams and breccia-hosted sulfide and sulfosalts seem to be associated with enrichment of silica as observed by geochemistry and petrography. It is demonstrated by the positive correlation between $\mathrm{SiO}_{2}$ and $\mathrm{Cu}$ in the L.L.S. and Transition Series from the assay data (Figure 9). This correlation is clear and shows an elevated concentration of silica reaching approximately $60 \%$ in $\mathrm{SiO}_{2}$, indicating a siliciclastic influence. Petrographic evidence of silicification is absent.

Another important post-depositional feature of the Tullacondra mineralization is the concentration of phyllosilicates along dissolution seams (Figure 8D). Our geochemical data suggest that phyllosilicates control the abundance of $\mathrm{Al}_{2} \mathrm{O}_{3}$ in Tullacondra rocks, although feldspars occur within siliciclastic rocks, and $\mathrm{Al}_{2} \mathrm{O}_{3}$ contents show a strong positive correlation with both $\mathrm{K}_{2} \mathrm{O}$ and $\mathrm{TiO}_{2}$ (Figure 10). These significant correlations are also observed in other barren or $\mathrm{Zn}-\mathrm{Pb}$ mineralized Irish Lower Carboniferous rocks [55,56]. They suggest that K-Ti-bearing phyllosilicates are common throughout the Irish Midlands and Munster basin. Whether these phyllosilicates are detrital or authigenic remains a contentious point, and their abundance is not a proxy for mineralization intensity. However, mineralized zones are generally phyllosilicate-bearing, an indication of a higher density of dissolution seams.

\subsection{Ore Formation Controls}

Our preliminary structural assessment of the Tullacondra deposit using legacy drill hole data and core logging information along with the spatial distribution of metal concentrations suggests a strong spatial correlation between mineralized zones and the E.W. fractured zone of the Tullacondra Fault (Figures 3 and 4). The role of this fracture system as an important channel for mineralizing fluids is suggested by the highest concentrations of $\mathrm{Cu}, \mathrm{Ag}, \mathrm{As}$, and $\mathrm{Sb}$. Percolating fluids would preferably deposit sulfides along strata on the hanging wall of the Tullacondra Fault, as evidenced by higher concentrations of $\mathrm{Cu}$ and $\mathrm{Ag}$ on the northern block. We thus interpret that the Tullacondra fault is a feeder zone through which mineralizing fluids percolated upwards and were channeled outwards along strata. Similar proximity of feeder faults and $\mathrm{Cu}-\mathrm{Ag}$ mineralization is described in Lisheen and Silvermines $[32,40,49,57]$. The possible source of the mineralizing fluid is the basement, as suggested by $\mathrm{Pb}$ isotope data of [28], similarly to what is proposed for other Irish $\mathrm{Zn}-\mathrm{Pb}$ deposits [58]

The abundance of mineralization associated with calcite replacement or dissolution (Figure 8A-C) contrasts with the low metal content of calcite-poor rocks of the O.R.S. [6]. This textural feature suggests that carbonate dissolution allowed copper and silver to precipitate as sulfides_additionally, the base of the L.L.S. also has higher organic matter concentration than underlying units, indicating favorable reducing conditions for mineralization. 
Reducing conditions offer a classic trap for sedimentary-hosted stratiform $\mathrm{Cu}$ deposits worldwide [59]. The mineralizing fluid from sedimentary-hosted stratiform $\mathrm{Cu}$ deposits flows during rifting through red beds and basement rocks, leaching metals and precipitating in marine and lacustrine organic-rich sediments [59]. The Irish $\mathrm{Cu}-\mathrm{Ag}$ deposits hosted within the L.L.S. Formation are underlain by red beds and hosted in marine organic-rich sediments from the Lower Carboniferous $[5,6,28]$. Magmatic activity as a possible source of metals and heat is considered for Irish $\mathrm{Cu}$ deposits and sedimentary-hosted stratiform $\mathrm{Cu}$ deposits elsewhere $[5,6,19,20,46,59]$. In this sense, Tullacondra shares similar controls with both $\mathrm{Zn}-\mathrm{Pb}$ Irish-type deposits and sedimentary-hosted $\mathrm{Cu}$ deposits.

\subsection{Paragenetic Sequence}

The paragenetic sequence of Tullacondra is represented in Figure 11. Pyrite paragenetic sequence is uncertain due to lack of spatial association with other ore minerals and framboidal pyrite. On the other hand, other Irish Cu deposits hosted in the L.L.S., such as Gortdrum and Ballyvergin, contain minor framboidal pyrite considered biogenic and the earliest sulfide phase [5,41]. In the $\mathrm{Zn}-\mathrm{Pb}$ deposits from the Irish Orefield, pyrite has been described in the pre-, main-, and post-ore phases $[33,36,38,40,60]$.

The textural relationships defined by chalcocite, bornite, and chalcopyrite at Tullacondra indicate that they precipitated simultaneously. This mineral paragenesis dominates the shallowest mineralized zone 2, hosted in the L.L.S, whereas it is subordinate to as ore minerals in samples from the deepest mineralized zone 1. Additionally, $\mathrm{Cu}$ sulfides likely mineralized firstly associated with Ag. Chemical correlations show that $\mathrm{Ag}$ is closely related to sulfur and $\mathrm{Cu}$ (Figures 9 and 10) and $\mathrm{Cu}$ sulfides (chalcocite, bornite, and chalcopyrite, Figure 8), whereas a chemical correlation between $\mathrm{Ag}$, $\mathrm{As}$, and $\mathrm{Sb}$ is not clear (Figures 9 and 10). Our EDS and petrographic analyses of $\mathrm{Cu}$ and As ore minerals failed to identify Ag-bearing phases [6] described native Ag mineralization in the Tullacondra deposit and confirmed that tennantite is not argentiferous. Similarly, at the Gortdrum $\mathrm{Cu}-\mathrm{Ag}-\mathrm{Hg}$ deposit, native $\mathrm{Ag}$ is associated with $\mathrm{Hg}$ or $\mathrm{Cu}$ minerals, such as stromeyerite (CuAgS) [5]. Thus, we suggest that Ag occurs as microscopic native Ag inclusions in $\mathrm{Cu}$-bearing minerals or an unidentified Ag-bearing phase.

This early assemblage of $\mathrm{Cu}$ sulfides associated with elevated $\mathrm{Ag}$ is followed by a second assemblage of fine- to medium-grained, disseminated, and dissolution seam-hosted tennantite-tetrahedrite, arsenopyrite, and chalcopyrite with medium-grained authigenic quartz and chalcedony (Figure 5H). The deposition sequence is evidenced by tennantite and arsenopyrite overlapping chalcocite, bornite, and chalcopyrite (Figure 5F,G). The Gortdrum deposit shows the same paragenetic sequence with an early $\mathrm{Cu}$ and a late $\mathrm{As}-\mathrm{Sb}$ mineralization. However, bornite and chalcocite are predominant in the lowermost parts, whereas the As minerals dominate in the uppermost units [5,61].

We suggest that the paragenetic sequence at Tullacondra, and likely at Gortdrum, was caused by (1) fluids from the same source but at different temperatures or (2) fluids sourced from different parts of the basement. Fluid inclusions studies of [5] in the Gortdrum deposit show that $\mathrm{Cu}$ sulfides were formed at a lower temperature $\left(\leq 100^{\circ} \mathrm{C}\right)$ in comparison with As ore minerals ( 140 to $180^{\circ} \mathrm{C}$ ). Thus, we propose a first mineralizing pulse bringing Ag and $\mathrm{Cu}$ from the basement deposit $\mathrm{Ag}$, preferentially within the Transition Series and $\mathrm{Cu}$ within the L.L.S. Later an As- and Cu-bearing fluid-of higher temperature or sourced from a different part of the basement-deposited As-bearing minerals in the Transition Series and chalcopyrite in the L.L.S. Thus, we subdivide the main ore-stage into early $\mathrm{Cu}-\mathrm{Ag}$ and late $\mathrm{Cu}$-As-Sb ore-stages. They are common to both shallow and deep mineralized zones, but the highest $\mathrm{Ag}$, As, and $\mathrm{Sb}$ grades occur in the deepest mineralized zone 1.

The vein-hosted ore cutting relationship with stratabound ores suggests remobilization of the ore fluids associated with late-ore stage veining. This stage caused the formation of the mineralized zone 3, which intersects the prior zones. This remobilization was likely formed by (re)activation of the Tullacondra fault either during the Lower Carboniferous 
extensional event or the Hercynian compression. The parallel orientation of the vertical mineralized zone 3 to the Tullacondra fault supports this idea.

Unlike other base metal deposits in Ireland, galena and sphalerite are largely absent at Tullacondra. Thus, if Tullacondra was formed as part of an Irish-type system, several characteristics could explain the differences in the metal budget: (a) the fluid was $\mathrm{Pb}$ - and $\mathrm{Zn}$-poor, (b) the fluid lacked the appropriate physicochemical conditions to deposit $\mathrm{Pb}$ and $\mathrm{Zn}$ minerals along with $\mathrm{Cu}, \mathrm{Sb}$, and $\mathrm{As}$ minerals, or (c) the Irish $\mathrm{Zn}-\mathrm{Pb}$ and $\mathrm{Cu}-\mathrm{Ag}$ mineralizing fluids were sourced from different parts of the basement. The $\mathrm{Cu}-\mathrm{Ag}$ deposits are underlain by thicker Devonian fluvial sediments relative to the $\mathrm{Zn}-\mathrm{Pb}$ deposits [28], and these sediments can also be a source of $\mathrm{Cu}$.

\begin{tabular}{|c|c|c|c|c|c|}
\hline \multirow[t]{3}{*}{ Time } & 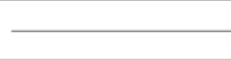 & 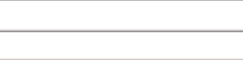 & 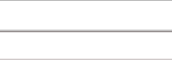 & +2 & $\longrightarrow$ \\
\hline & \multicolumn{2}{|c|}{ Pre-ore stage } & \multicolumn{2}{|c|}{ Main-ore stages } & \multirow[t]{2}{*}{ Late-ore stage } \\
\hline & Syn-depositional & Post-depositional & Early Cu-Ag & Late $\mathrm{Cu}-\mathrm{As}-\mathrm{Sb}$ & \\
\hline Calcite & & & & & \\
\hline Quartz, Chalcedony, Feldspar & & & & & --- \\
\hline Monazite, zircon, rutile, ilmenite & & & & & \\
\hline Hematite & 乙 & & & & \\
\hline Phyllosilicates & & ??? & & & \\
\hline Dolomite & & $---\longrightarrow$ & & & \\
\hline Apatite, chlorite & & & & & - - - \\
\hline Pyrite & & $?$ & - ? & & \\
\hline Chalcopyrite & & & & & \\
\hline Chalcocite, bornite & & & $=$ & & \\
\hline Tennantite-tetrahedrite, arsenopyrite & & & & & \\
\hline
\end{tabular}

Figure 11. Proposed paragenetic sequence of the Tullacondra deposit.

\subsection{Genetic Model}

The Tullacondra deposit consists of two earlier mineralized zones cut by a latter vertical zone. The timing of these events is unknown, albeit Tullacondra shares many similarities in mineral content, textures, alterations, and structural control with other $\mathrm{Cu}-\mathrm{Ag}$ deposits in the Irish Midlands, such as the Gortdrum, Aherlow, and Ballyvergin [5,6,28,41,43]. Therefore, we discuss two possibilities: (1) formation during the Lower Carboniferous extensional event, also responsible for the mineralization of other Irish $\mathrm{Zn}-\mathrm{Pb}$ deposits; (2) formation during the Hercynian compression at the end of the Carboniferous.

An important argument to support Tullacondra mineralization as formed in the Lower Carboniferous relies on the recurring role of dissolution seams in hosting sulfides. In Tullacondra, these are bedding-parallel dissolution structures, suggestive of formation during burial [62]. Plane axial cleavage associated with compression [21,25] has not been identified in our data, nor cleavage-hosted sulfides. Later reactivation could explain the cutting relationship between stratabound ores by vein-related ores (Figure 8A-D). Besides, Tullacondra sits in the transitional deformational zone of [24], which shares structural characteristics between the more deformed zone 1 (southern KMFZ) and the less deformed zone 2 (northern KMFZ). It means that the sedimentary and diagenetic features could be well preserved at Tullacondra, such as stylolites, although this area is also folded and thrusted. 
Another strong line of evidence suggesting that Tullacondra formed mostly during the Late Carboniferous is the ore geometry, mineralogy, and textures with Irish $\mathrm{Zn}-\mathrm{Pb}$ deposits. The main similarity is sulfide deposition on the hanging wall of a feeder fault that was later reactivated during regional Hercynian compression [22,63]. Irish $\mathrm{Zn}-\mathrm{Pb}$ deposits also contain $\mathrm{Cu}$ and As sulfides and sulfosalts closer to the feeder zone [36,38-40], and these minerals are later than sphalerite and galena in the paragenetic sequence.

Strong evidence for a Late Carboniferous, basin-wide $\mathrm{Cu}$-Ag mineralization comes from $\mathrm{Pb}-\mathrm{Pb}$ isotope data from occurrences hosted within the L.L.S. Formation around Kilarney-the Ross Island and Crow Island, Muckross $\mathrm{Cu}$ and Ag plays [28]. These occurrences have $\mathrm{Pb}-\mathrm{Pb}$ signatures compatible with the Paleozoic basement and provide errorchron ages of $355+10$ for Muckross and $350+10$ for Crow Island [28]. Irish Zn-Pb deposits show similar isotopic $\mathrm{Pb}-\mathrm{Pb}$ isotope results [58]. Additionally, the errorchron ages for these carbonate-hosted $\mathrm{Cu}$-Ag occurrences coincide with the interpreted age range of Irish $\mathrm{Zn}$ - $\mathrm{Pb}$ deposits [28] and with whole-rock $\mathrm{U}-\mathrm{Pb}$ ages of $340+25 \mathrm{Ma}$ and $\mathrm{Pb}-\mathrm{Pb}$ ages of $359+26 \mathrm{Ma}$ for the Gortdrum Cu-Ag deposit [42]. Copper circulated in the Munster Basin even before the Irish Midlands Basin deposition, as shown by molybdenite Re-Os dating ( $367.3 \pm 5.5$ to $366.4 \pm 1.9 \mathrm{Ma}$ ) of main-stage $\mathrm{Cu}$ veins from Allihies mine in southwestern Ireland [45]. Therefore, even though geochronological data lacks in Tullacondra, its similarities with other carbonate-hosted $\mathrm{Cu}-\mathrm{Ag}$ deposits and Irish-type $\mathrm{Zn}-\mathrm{Pb}$ deposits suggest a common origin. However, if Irish carbonate-hosted $\mathrm{Cu}-\mathrm{Ag}$ deposits are formed by metalbearing brines reacting with reduced host rocks, their mineralizing process differs from Irish $\mathrm{Zn}-\mathrm{Pb}$ deposits. The $\mathrm{Zn}-\mathrm{Pb}$ mineralization of Ireland is mostly formed by the mixing of metal-bearing brines with a reduced basinal fluid flowing through the host rocks [56]. These distinctions suggest that even if the Irish $\mathrm{Cu}$ and $\mathrm{Zn}-\mathrm{Pb}$ deposits were formed roughly simultaneously, their mineralizing processes could have important differences.

The formation of the Tullacondra deposit during the Hercynian orogeny could be argued based on its location within the hinge of an anticline (Figure 1). Many of the major and small faults in this region of southern Ireland are subparallel to the axial trace of the Variscan folds in the region and are thought of as thrust faults [24,25]. Additionally, the structures described here as dissolutions seams are texturally similar to solution cleavages described in the Munster Basin and the southern Irish Midlands [25-27]. These could suggest that the Tullacondra fault and the seams formed during Hercynian compression. However, this work favors the interpretation that Tullacondra mineralization was largely contemporaneous to other $\mathrm{Cu}-\mathrm{Ag}$ and $\mathrm{Zn}-\mathrm{Pb}$ deposition in the Irish Midlands. The role of post-Late Carboniferous events in the Tullacondra deposit was largely of (a) remobilizing the metals and depositing sulfides as veins and (b) reactivating the fault system that acted as feeding conduits for metal-bearing fluids.

\section{Conclusions}

The Tullacondra $\mathrm{Cu}-\mathrm{Ag}$ deposit is similar to other small Irish $\mathrm{Cu}$ deposits within the L.L.S., such as Gortdrum, Aherlow, and Ballyvergin. The shaly limestone-hosted Tullacondra deposit contains at least three mineralized zones: (a) the Transition Serieshosted mineralized zone containing elevated $\mathrm{Ag}$, $\mathrm{As}$, and $\mathrm{Sb}$ from two different events (An early $\mathrm{Cu}-\mathrm{Ag}$ and a late As-Sb low Ag stage); (b) the L.L.S.-hosted mineralized zone, dominated by $\mathrm{Cu}$ sulfides, and (c) a near-vertical mineralized zone associated with fractures related to the Tullacondra Fault.

We propose that the genesis of the Tullacondra deposit can be divided into pre-ore, main-ore, and late-ore stages based on the interpretation of our data:

1. Pre-ore stage: this stage is characterized by the onset of EW-trending faulting (Tullacondra Fault). The formation of the Tullacondra Fault likely resulted in subsidiary faults and fractures, which later would serve as conduits for mineralizing fluids.

2. The Main-ore stage is characterized by the deposition of the sulfides and the formation of the mineralized zones 1 and 2 . The fluid flowed laterally and upwards along the Tullacondra fault, precipitating sulfides and sulfosalts along stratigraphic boundaries. 
Variations of sulfide composition are attributed to two distinct mineralizing pulses, an earlier $\mathrm{Cu}$ - and $\mathrm{Ag}$-bearing fluid and a later $\mathrm{Cu}$ - and As-bearing fluid.

3. The late-ore stage is marked by the remobilization of metals in sparitic calcite and dolomite veins, forming the vertical mineralized zone. The timing of this stage is unknown, and we are unable to establish whether it shortly post-dates the main ore stage or if it is associated with an even later stage, such as the Hercynian compression.

This work could not clarify a genetic relationship between Tullacondra and the $\mathrm{Zn}-\mathrm{Pb}$ mineralization event associated with Irish-type deposits. However, the deposition of $\mathrm{Cu}$ sulfides, mostly within the hanging wall of the Tullacondra Fault and along beddingparallel dissolution seams, suggests an epigenetic character for the mineralization with a strong resemblance to similar feeder fault-proximal $\mathrm{Cu}$ sulfides in Lisheen and Silvermines. The role of mixing of basement-derived and basin-derived fluids, as per Irish-type mineralization, remains elusive. For Tullacondra, we suggest that the main mineralizing mechanism was the interaction between a metal-bearing fluid and carbonate rocks from the L.L.S. and Transition Series.

Supplementary Materials: The following are available online at https://www.mdpi.com/article/10 $.3390 / \mathrm{min} 11060560 / \mathrm{s} 1$. Table S1: Whole-rock assay of Tullacondra deposit rocks.

Author Contributions: Conceptualization, P.C., A.A.S., S.C.J., P.A.M.; methodology, P.C., L.C., A.A.S., A.M.S., L.S.C., L.E.L., A.S.; software, A.A.S., P.C.; formal analysis, A.A.S., P.C., S.C.J.; investigation, A.A.S., A.M.S., L.S.C., P.C., L.C.; resources, P.C., P.A.M., R.U., A.S.; data curation, A.A.S., L.C.; writing—original draft preparation, A.A.S., P.C.; writing—review and editing, A.S., P.A.M., R.U., L.E.L., S.C.J.; funding acquisition, P.A.M., R.U. All authors have read and agreed to the published version of the manuscript.

Funding: This research was carried out as part of a post-doctoral research position by P.C. at the University College Cork, supported by a research grant from Science Foundation Ireland (S.F.I.) under Grant Number 13/R.C./2092 and is co-funded under the European Regional Development Fund and by iCRAG industry partners, as well as S.F.I. research grant 16/R.P./3849. Part of this research was also funded by Diversified Asset Holdings Pty Ltd., which held the exploration licenses at the time of this research, and by the Seed Fund 2018 under CORFO 14ENI2-26862 of the School of Engineering of the Pontifical Catholic University of Chile. Special thanks are also given to the Coordenação de Aperfeiçoamento de Pessoal de Nível Superior (CAPES) for the MSc scholarship granted to the first author under Grant Number 88882.382055/2019-01.

Institutional Review Board Statement: Not applicable.

Informed Consent Statement: Not applicable.

Data Availability Statement: The geological maps of Ireland and the region around the Tullacondra deposit (Figures 1B, 2 and 3) are based on data available by the Geological Survey Ireland (G.S.I.). These data are available on https:/ / www.gsi.ie/en-ie/data-and-maps/Pages/default.aspx (accessed on 18 April 2021).

Acknowledgments: The authors gratefully acknowledge the Geological Survey Ireland for access to core samples and preserve the Tullacondra Deposit legacy data. We are also grateful for the contributions of anonymous reviewers who contributed to an earlier version of this manuscript.

Conflicts of Interest: The authors declare that the mainly results of the research are part of the master's dissertation of the main author from graduation program at UFPR (Curitiba, Brazil). The authors declare no conflict of interest. 


\section{Appendix A}

Table A1. Stratigraphy in the Tullacondra deposit according to [6].

\begin{tabular}{|c|c|c|c|c|}
\hline & \multicolumn{2}{|c|}{ Lithological Units } & Thickness & Description \\
\hline & \multicolumn{2}{|c|}{ Kilmaclenine Ls } & $100 \mathrm{~m}$ & Pale grey, thick-bedded bioclastic limestone, often shale free \\
\hline 度 & \multicolumn{2}{|c|}{ Tullacondra Ls } & $35 \mathrm{~m}$ & $\begin{array}{c}\text { Medium grey, crinoidal with thin irregular shale partings, } \\
\text { siliciclastic at the base }\end{array}$ \\
\hline U & \multirow{2}{*}{\multicolumn{2}{|c|}{$\begin{array}{l}\text { Ballyvergin Shale } \\
\text { Upper Shaly } \\
\text { Calcarenite }\end{array}$}} & $1 \mathrm{~m}$ & Fine, sandy, non-calcareous, green-grey siltstone \\
\hline 光 & & & $15-20 \mathrm{~m}$ & $\begin{array}{l}\text { Medium grey crinoidal calcarenite, abundant shale partings, } \\
\text { siliceous at the top }\end{array}$ \\
\hline w & \multirow{6}{*}{ 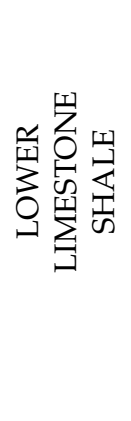 } & & $2 \mathrm{~m}$ & Dark grey muddy calcarenite \\
\hline$\underset{\substack{0 \\
\frac{1}{1}}}{2}$ & & $\begin{array}{l}\text { Oolitic } \\
\text { Calcarenite }\end{array}$ & $9-12 \mathrm{~m}$ & Interbedded oolites and crinoidal calcarenites \\
\hline$\sum_{0}^{1}$ & & $\begin{array}{l}\text { Lower Shaly } \\
\text { Calcarenite }\end{array}$ & $6-9 \mathrm{~m}$ & Uniform, pale calcarenite with interbedded, shaly crinoidal units \\
\hline 党 & & $\begin{array}{l}\text { Uniform } \\
\text { Calcarenite }\end{array}$ & $5-6 \mathrm{~m}$ & Pale massive calcarenite, mostly shale free \\
\hline$\frac{\sqrt[c]{u}}{4}$ & & $\begin{array}{l}\text { Upper (Shaly) } \\
\text { Transition Series }\end{array}$ & $12-15 \mathrm{~m}$ & $\begin{array}{l}\text { Black shales, sandy calcarenites, and sandstones }-0.3 \mathrm{~m} \text { Hematitic } \\
\text { Horizon near the base }\end{array}$ \\
\hline 3 & & $\begin{array}{l}\text { Lower (Sandy) } \\
\text { Transition Series }\end{array}$ & $12-15 \mathrm{~m}$ & Sandstones, shales, and conglomerates, often calcareous \\
\hline \multicolumn{2}{|c|}{ DEVONIAN } & $\begin{array}{l}\text { Old Red } \\
\text { Sandstone }\end{array}$ & $>500 \mathrm{~m}$ & Shales, quartzitic sandstones, conglomerates, and red beds \\
\hline
\end{tabular}

Table A2. Texture and ore minerals.

\begin{tabular}{|c|c|c|c|c|c|}
\hline Samples & Area & Units & Texture & Ore Mineralagy & $\%$ Ore Minerals \\
\hline M73-3-027 & Western area & Tullacondra Ls & - & $\begin{array}{l}\text { supergene } \\
\text { minerals }\end{array}$ & - \\
\hline M73-3-039 & Western area & Tullacondra Ls & disseminated/vein-hosted & ccp, cct, bn $>>$ py & $2 \%$ \\
\hline M73-3-069 & Western area & Tullacondra Ls & - & $\begin{array}{l}\text { supergene } \\
\text { minerals }\end{array}$ & - \\
\hline M73-3-094 & Western area & Tullacondra Ls & disseminated/vein-hosted & cct, bn $>>$ py & $2 \%$ \\
\hline M73-3-119 & Western area & Ballyvergin Shale & $\begin{array}{l}\text { bedding-paralel/dissolution } \\
\text { seam-hosted/vein-hosted }\end{array}$ & $\mathrm{cct}, \mathrm{bn}, \mathrm{ccp}$ & $3 \%$ \\
\hline M73-3-132 & Western area & Lower Ls Shale & $\begin{array}{l}\text { disseminated/dissolution } \\
\text { seam-hosted }\end{array}$ & $\begin{array}{c}\text { cct, bn, ccp }>\text { tnt, } \\
\text { apy }\end{array}$ & $2 \%$ \\
\hline M73-3-143 & Western area & Lower Ls Shale & $\begin{array}{c}\text { disseminated/dissolution seam- } \\
\text { hosted }\end{array}$ & $\begin{array}{c}\text { cct, bn, ccp }>\text { tnt, } \\
\text { apy }\end{array}$ & $5 \%$ \\
\hline M73-3-154 & Western area & Lower Ls Shale & $\begin{array}{l}\text { disseminated/dissolution } \\
\text { seam-hosted }\end{array}$ & $\begin{array}{c}\text { cct, bn, ccp }>\text { tnt, } \\
\text { apy }\end{array}$ & $3 \%$ \\
\hline M73-3-162 & Western area & Lower Ls Shale & $\begin{array}{l}\text { disseminated/dissolution } \\
\text { seam-hosted }\end{array}$ & $\begin{array}{l}\text { cct, bn, ccp > tnt, } \\
\text { ttr, apy }\end{array}$ & $5 \%$ \\
\hline M73-3-196 & Western area & Lower Ls Shale & disseminated & ccp > tnt, apy & $3 \%$ \\
\hline M73-3-203 & Western area & Lower Ls Shale & disseminated & ccp $>$ tnt, apy & $1 \%$ \\
\hline M73-3-218 & Western area & Lower Ls Shale & disseminated & ccp > tnt, apy & $1 \%$ \\
\hline Samples & Area & Units & Texture & Ore mineralagy & $\%$ ore minerals \\
\hline M73-3-233 & Western area & Lower Ls Shale & $\begin{array}{l}\text { disseminated/dissolution } \\
\text { seam-hosted }\end{array}$ & ccp > tnt, apy & $2 \%$ \\
\hline M73-3-241 & Western area & Lower Ls Shale & disseminated & cсp & $<1 \%$ \\
\hline M73-3-283 & Western area & Lower Ls Shale & disseminated & ccp & $<1 \%$ \\
\hline M73-3-293 & Western area & Lower Ls Shale & disseminated & сcp & $<1 \%$ \\
\hline M73-3-318 & Western area & Lower Ls Shale & $\begin{array}{l}\text { disseminated/dissolution } \\
\text { seam-hosted }\end{array}$ & ccp, tnt $>$ apy & $3 \%$ \\
\hline M73-3-328 & Western area & Lower Ls Shale & $\begin{array}{c}\text { disseminated/dissolution } \\
\text { seam-hosted }\end{array}$ & ccp, tnt $>$ apy & $3 \%$ \\
\hline M73-3-347 & Western area & Lower Ls Shale & disseminated & ccp > tnt, apy & $1 \%$ \\
\hline M73-3-374 & Western area & Transition Series & disseminated & ccp > tnt, apy & $<1 \%$ \\
\hline M73-3-393 & Western area & Transition Series & vein-hosted & ccp, tnt, ttr $>$ apy & $3 \%$ \\
\hline
\end{tabular}


Table A2. Cont.

\begin{tabular}{|c|c|c|c|c|c|}
\hline Samples & Area & Units & Texture & Ore Mineralagy & $\%$ Ore Minerals \\
\hline M73-11-290 & Central area & Lower Ls Shale & $\begin{array}{c}\text { disseminated/dissolution } \\
\text { seam-hosted }\end{array}$ & Py & $2 \%$ \\
\hline M73-11-296 & Central area & Lower Ls Shale & $\begin{array}{l}\text { disseminated/bedding- } \\
\text { paralel/dissolution } \\
\text { seam-hosted }\end{array}$ & $\mathrm{Bn}>>\mathrm{cct}, \mathrm{ccp}>\mathrm{tnt}$ & $2 \%$ \\
\hline M73-11-310 & Central area & Lower Ls Shale & $\begin{array}{l}\text { disseminated/dissolution } \\
\text { seam-hosted }\end{array}$ & bn, $c c p>$ tnt & $1 \%$ \\
\hline M73-11-319 & Central area & Lower Ls Shale & $\begin{array}{c}\text { disseminated/dissolution } \\
\text { seam-hosted }\end{array}$ & Ccp $>>$ bn, tnt & $1 \%$ \\
\hline M73-11-336 & Central area & Lower Ls Shale & disseminated & Ccp $>$ bn, tnt & $<1 \%$ \\
\hline M73-11-347 & Central area & Lower Ls Shale & disseminated & $\mathrm{Bn} \gg>\mathrm{cct}, \mathrm{ccp}>\mathrm{tnt}$ & $<1 \%$ \\
\hline M73-11-359 & Central area & Lower Ls Shale & disseminated/vein-hosted & cct, bn $>>$ tnt & $1 \%$ \\
\hline M73-11-389 & Central area & Lower Ls Shale & vein-hosted & bn, $\mathrm{ccp}$ & $<1 \%$ \\
\hline M73-11-404 & Central area & Lower Ls Shale & disseminated & Ccp $>$ bn, tnt & $<1 \%$ \\
\hline M73-11-422 & Central area & Transition Series & $\begin{array}{l}\text { disseminated/bedding- } \\
\text { paralel/dissolution } \\
\text { seam-hosted/vein-hosted }\end{array}$ & $\begin{array}{c}\text { Bn }>>c c p, \text { tnt }> \\
\text { apy }\end{array}$ & $5 \%$ \\
\hline M73-11-442 & Central area & Transition Series & disseminated/vein-hosted & bn, ccp, tnt $>$ apy & $2 \%$ \\
\hline M73-11-450 & Central area & Transition Series & disseminated & bn, ccp, tnt $>$ apy & $1 \%$ \\
\hline M73-11-510 & Central area & Old Red Sandsone & disseminated/vein-hosted & - & $<1 \%$ \\
\hline M73-19-72 & Eastern area & Lower Ls Shale & $\begin{array}{l}\text { disseminated/dissolution } \\
\text { seam-hosted/vein-hosted }\end{array}$ & cct, bn, ccp & $5 \%$ \\
\hline M73-19-133 & Eastern area & Lower Ls Shale & $\begin{array}{l}\text { disseminated/dissolution } \\
\text { seam-hosted/vein-hosted }\end{array}$ & $\begin{array}{c}\text { cct, bn, ccp }>>\text { tnt, } \\
\text { ttr }>\text { py }\end{array}$ & $5 \%$ \\
\hline M73-19-142 & Eastern area & Lower Ls Shale & disseminated/vein-hosted & $c c t, b n, c c p>>$ tnt & $2 \%$ \\
\hline M7319-172 & Eastern area & Lower Ls Shale & $\begin{array}{l}\text { disseminated/dissolution } \\
\text { seam-hosted/vein-hosted }\end{array}$ & $\mathrm{cc}, \mathrm{bn}, \mathrm{ccp}$ & $2 \%$ \\
\hline M73-19-249 & Eastern area & Transition Series & $\begin{array}{l}\text { disseminated/dissolution } \\
\text { seam-hosted/vein-hosted }\end{array}$ & tnt $>>c c$, bn, $c c p$ & $3 \%$ \\
\hline M73-19-257 & Eastern area & Transition Series & disseminated & tnt $>>c c, b n, c c p$ & $2 \%$ \\
\hline M73-19-264 & Eastern area & Transition Series & disseminated & tnt $>>c c, b n, c c p$ & $2 \%$ \\
\hline M73-19-271 & Eastern area & Transition Series & disseminated & tnt $>>c c, b n, c c p$ & $2 \%$ \\
\hline M7319-279 & Eastern area & Transition Series & disseminated & tnt $>>c c, b n, c c p$ & $2 \%$ \\
\hline M73-19-296 & Eastern area & Transition Series & disseminated & tnt & $1 \%$ \\
\hline
\end{tabular}

Table A3. Geochemical data.

\begin{tabular}{|c|c|c|c|c|c|c|c|c|c|c|c|c|c|c|c|c|}
\hline Samples & & Petrog. & EDS & Assay & $\begin{array}{l}\text { micro- } \\
\text { XRF }\end{array}$ & $\begin{array}{c}\mathrm{SiO}_{2} \\
(\%)\end{array}$ & $\begin{array}{c}\mathrm{Al}_{2} \mathrm{O}_{3} \\
(\%)\end{array}$ & $\begin{array}{c}\mathrm{CaO} \\
(\%)\end{array}$ & $\underset{(\%)}{\mathrm{MgO}}$ & $\begin{array}{c}\mathrm{K}_{2} \mathrm{O} \\
(\%)\end{array}$ & $\begin{array}{l}\mathrm{TiO}_{2} \\
(\%)\end{array}$ & $\underset{(p p m)}{\mathrm{Cu}}$ & $\underset{(\mathrm{ppm})}{\mathrm{Ag}}$ & $\begin{array}{c}\text { As } \\
(\mathrm{ppm})\end{array}$ & $\begin{array}{l}\mathrm{Sb} \\
(\mathrm{ppm})\end{array}$ & $\begin{array}{c}\mathrm{S} \\
(\%)\end{array}$ \\
\hline $\begin{array}{c}\text { M73-3- } \\
027\end{array}$ & $\begin{array}{l}\text { Tullacondra } \\
\text { Ls }\end{array}$ & $x$ & & $x$ & & 7.29 & 1.1 & 28.3 & 17.55 & 0.41 & 0.05 & 5130 & $<0.5$ & 4.2 & 2 & $<0.01$ \\
\hline $\begin{array}{c}\text { M73-3- } \\
039\end{array}$ & $\begin{array}{l}\text { Tullacondra } \\
\text { Ls }\end{array}$ & $x$ & & $x$ & & 5 & 0.76 & 50.1 & 0.57 & 0.28 & 0.03 & $>10,000$ & 20.2 & 8.6 & 14.6 & 0.19 \\
\hline $\begin{array}{c}\text { M73-3- } \\
069\end{array}$ & $\begin{array}{l}\text { Tullacondra } \\
\text { Ls }\end{array}$ & $x$ & & $x$ & & 7.21 & 0.27 & 51.6 & 0.48 & 0.12 & 0.01 & 463 & 0.5 & 11.5 & 0.73 & 0.03 \\
\hline $\begin{array}{c}\text { M73-3- } \\
094\end{array}$ & $\begin{array}{c}\text { Tullacondra } \\
\text { Ls }\end{array}$ & $x$ & $x$ & $x$ & $x$ & 38.5 & 0.5 & 34.1 & 0.38 & 0.19 & 0.02 & 782 & 3.1 & 0.9 & 0.17 & 0.07 \\
\hline $\begin{array}{l}\text { M73-3- } \\
119\end{array}$ & $\begin{array}{l}\text { Ballyvergin } \\
\text { Shale }\end{array}$ & $X$ & $x$ & $x$ & $x$ & 61.1 & 15.1 & 6.13 & 1.33 & 4.91 & 0.78 & 9000 & 46.6 & 8.3 & 0.39 & 0.37 \\
\hline $\begin{array}{l}\text { M73-3- } \\
132\end{array}$ & $\begin{array}{l}\text { Upper Shaly } \\
\text { Calcarenite }\end{array}$ & $x$ & & $X$ & & 23 & 2.28 & 40 & 0.88 & 0.71 & 0.09 & 3510 & 14.5 & 2.1 & 0.22 & 0.25 \\
\hline $\begin{array}{c}\text { M73-3- } \\
143\end{array}$ & $\begin{array}{l}\text { Upper Shaly } \\
\text { Calcarenite }\end{array}$ & $x$ & & $x$ & & 69.1 & 8.01 & 9.59 & 0.72 & 2.56 & 0.33 & $>10,000$ & 1.4 & 44.3 & 1.93 & 1.1 \\
\hline $\begin{array}{c}\text { M73-3- } \\
154\end{array}$ & $\begin{array}{l}\text { Upper Shaly } \\
\text { Calcarenite }\end{array}$ & $x$ & $x$ & $x$ & & 26.4 & 3.67 & 35.7 & 0.75 & 1.19 & 0.16 & 2450 & 13.1 & 80.6 & 12.35 & 0.17 \\
\hline $\begin{array}{c}\text { M73-3- } \\
162\end{array}$ & $\begin{array}{l}\text { Upper Shaly } \\
\text { Calcarenite }\end{array}$ & $x$ & $x$ & $x$ & $x$ & 39.2 & 7.56 & 20.1 & 4.9 & 2.51 & 0.31 & 4010 & 3.7 & 97.6 & 77 & 0.33 \\
\hline $\begin{array}{c}\text { M73-3- } \\
196\end{array}$ & $\begin{array}{l}\text { Upper Shaly } \\
\text { Calcarenite }\end{array}$ & $x$ & $x$ & $x$ & $x$ & 7.38 & 1.06 & 28.4 & 18.7 & 0.35 & 0.06 & 6930 & 0.7 & 8 & 4.4 & 0.44 \\
\hline $\begin{array}{l}\text { M73-3- } \\
203\end{array}$ & $\begin{array}{l}\text { Upper Shaly } \\
\text { Calcarenite }\end{array}$ & $X$ & & $x$ & & 3.83 & 0.71 & 29.9 & 19.55 & 0.25 & 0.02 & 1650 & $<0.5$ & 3.9 & 0.63 & 0.08 \\
\hline $\begin{array}{c}\text { M73-3- } \\
218\end{array}$ & $\begin{array}{l}\text { Upper Shaly } \\
\text { Calcarenite }\end{array}$ & $x$ & $x$ & $x$ & & 7.42 & 1.08 & 28.3 & 17.7 & 0.35 & 0.04 & 654 & $<0.5$ & 1.7 & 0.22 & 0.03 \\
\hline $\begin{array}{c}\text { M73-3- } \\
233\end{array}$ & $\begin{array}{l}\text { Upper Shaly } \\
\text { Calcarenite }\end{array}$ & $x$ & $X$ & $x$ & & 63 & 15.5 & 3.32 & 2.89 & 4.74 & 0.83 & 2470 & $<0.5$ & 70.2 & 0.7 & 0.28 \\
\hline
\end{tabular}


Table A3. Cont.

\begin{tabular}{|c|c|c|c|c|c|c|c|c|c|c|c|c|c|c|c|c|}
\hline Samples & & Petrog. & EDS & Assay & $\begin{array}{l}\text { micro- } \\
\text { XRF }\end{array}$ & $\begin{array}{c}\mathrm{SiO}_{2} \\
(\%)\end{array}$ & $\underset{(\%)}{\mathrm{Al}_{2} \mathrm{O}_{3}}$ & $\begin{array}{c}\mathrm{CaO} \\
(\%)\end{array}$ & $\underset{(\%)}{\mathrm{MgO}}$ & $\begin{array}{r}\mathrm{K}_{2} \mathrm{O} \\
(\%)\end{array}$ & $\begin{array}{c}\mathrm{TiO}_{2} \\
(\%)\end{array}$ & $\begin{array}{c}\mathrm{Cu} \\
(\mathrm{ppm})\end{array}$ & $\underset{(\mathrm{ppm})}{\mathrm{Ag}}$ & $\begin{array}{c}\text { As } \\
(\mathrm{ppm})\end{array}$ & $\begin{array}{l}\mathrm{Sb} \\
(\mathrm{ppm})\end{array}$ & $\begin{array}{c}\mathrm{S} \\
(\%)\end{array}$ \\
\hline $\begin{array}{c}\text { M73-3- } \\
241\end{array}$ & $\begin{array}{l}\text { Upper Shaly } \\
\text { Calcarenite }\end{array}$ & $X$ & & $X$ & & 8.94 & 0.63 & 28.2 & 17.05 & 0.24 & 0.04 & 65 & $<0.5$ & 4 & 0.32 & 0.02 \\
\hline $\begin{array}{c}\text { M73-3- } \\
254\end{array}$ & $\begin{array}{l}\text { Upper Shaly } \\
\text { Calcarenite }\end{array}$ & $X$ & $X$ & $X$ & & 58.8 & 20.4 & 0.39 & 2.14 & 5.89 & 0.92 & 41 & $<0.5$ & 28.7 & 0.64 & 0.41 \\
\hline $\begin{array}{c}\text { M73-3- } \\
283\end{array}$ & $\begin{array}{c}\text { Oolitic } \\
\text { Calcarenite }\end{array}$ & $x$ & $x$ & $X$ & & 9.58 & 0.54 & 27.8 & 17.1 & 0.23 & 0.02 & 9 & $<0.5$ & 48.5 & 0.66 & 0.14 \\
\hline $\begin{array}{c}\text { M73-3- } \\
293\end{array}$ & $\begin{array}{c}\text { Oolitic } \\
\text { Calcarenite }\end{array}$ & $X$ & $X$ & $X$ & & 18 & 2.25 & 24 & 15 & 0.77 & 0.11 & 21 & $<0.5$ & 2 & 0.09 & 0.04 \\
\hline $\begin{array}{c}\text { M73-3- } \\
318\end{array}$ & $\begin{array}{l}\text { Lower Shaly } \\
\text { Calcarenite }\end{array}$ & $x$ & $x$ & $X$ & & 52.1 & 13.45 & 8.85 & 2.79 & 4.3 & 0.61 & 7120 & $<0.5$ & 13.2 & 0.9 & 0.73 \\
\hline $\begin{array}{l}\text { M73-3- } \\
328\end{array}$ & $\begin{array}{l}\text { Lower Shaly } \\
\text { Calcarenite }\end{array}$ & $x$ & $x$ & $X$ & $x$ & 57.7 & 12.9 & 5.46 & 3.89 & 4.22 & 0.57 & $>10,000$ & $<0.5$ & 22.2 & 1.15 & 1.25 \\
\hline $\begin{array}{c}\text { M73-3- } \\
347\end{array}$ & $\begin{array}{l}\text { Uniform } \\
\text { Calcarenite }\end{array}$ & $x$ & $x$ & $X$ & & 81.8 & 8.26 & 0.79 & 0.51 & 2.71 & 0.53 & 9830 & 1.7 & 72.7 & 25.6 & 1.1 \\
\hline $\begin{array}{l}\text { M73-3- } \\
364\end{array}$ & $\begin{array}{c}\text { Upper } \\
\text { Transition } \\
\text { Series }\end{array}$ & & $x$ & $X$ & & 62.9 & 3.5 & 8.91 & 5.88 & 1.19 & 0.47 & 3510 & 2.4 & 15 & 0.76 & 0.23 \\
\hline $\begin{array}{l}\text { M73-3- } \\
374\end{array}$ & $\begin{array}{c}\text { Upper } \\
\text { Transition } \\
\text { Series }\end{array}$ & $x$ & $x$ & $X$ & & 66 & 6.76 & 6.39 & 4.47 & 2.25 & 0.35 & 1350 & $<0.5$ & 23.6 & 5.99 & 0.14 \\
\hline $\begin{array}{c}\text { M73-3- } \\
393\end{array}$ & $\begin{array}{l}\text { Lower } \\
\text { Transition } \\
\text { Series }\end{array}$ & $x$ & $X$ & $X$ & $X$ & 50.2 & 11.9 & 7.5 & 5.61 & 3.89 & 0.61 & $>10,000$ & 1.5 & $>250$ & $>250$ & 1.64 \\
\hline $\begin{array}{c}\text { M73-3- } \\
412\end{array}$ & $\begin{array}{l}\text { Lower } \\
\text { Transition } \\
\text { Series }\end{array}$ & $x$ & $X$ & $X$ & & 90.5 & 4.24 & 0.82 & 0.66 & 1.42 & 0.2 & 18 & $<0.5$ & 0.5 & 0.12 & 0.01 \\
\hline $\begin{array}{c}\text { M73-11- } \\
290\end{array}$ & $\begin{array}{l}\text { Upper Shaly } \\
\text { Calcarenite }\end{array}$ & $x$ & & $X$ & $x$ & 27.2 & 6.58 & 31.5 & 1.43 & 1.95 & 0.27 & 15 & $<0.5$ & $>250$ & 1.07 & 0.49 \\
\hline $\begin{array}{l}\text { M73-11- } \\
296\end{array}$ & $\begin{array}{l}\text { Upper Shaly } \\
\text { Calcarenite }\end{array}$ & $x$ & & $x$ & & 60.9 & 8.17 & 12.1 & 0.9 & 2.37 & 0.34 & 5250 & 45 & 17.2 & 0.13 & 0.32 \\
\hline $\begin{array}{c}\text { M73-11- } \\
310\end{array}$ & $\begin{array}{c}\text { Upper Shaly } \\
\text { Calcarenite }\end{array}$ & & & $x$ & & 35.1 & 8.67 & 22.9 & 1.43 & 2.64 & 0.38 & $>10,000$ & $>100$ & 22.4 & 0.07 & 1.13 \\
\hline $\begin{array}{l}\text { M73-11- } \\
319\end{array}$ & $\begin{array}{l}\text { Upper Shaly } \\
\text { Calcarenite }\end{array}$ & $X$ & & $X$ & $X$ & 5.79 & 0.89 & 51 & 0.65 & 0.28 & 0.05 & 1520 & 0.9 & 12.9 & 0.47 & 0.33 \\
\hline Samples & & Petrog. & EDS & Assay & $\underset{X R F}{\text { micro- }}$ & $\underset{(\%)}{\mathrm{SiO}_{2}}$ & $\underset{(\%)}{\mathrm{Al}_{2} \mathrm{O}_{3}}$ & $\begin{array}{c}\mathrm{CaO} \\
(\%)\end{array}$ & $\underset{(\%)}{\mathrm{MgO}}$ & $\begin{array}{c}\mathrm{K}_{2} \mathrm{O} \\
(\%)\end{array}$ & $\underset{(\%)}{\mathrm{TiO}_{2}}$ & $\begin{array}{c}\mathrm{Cu} \\
(\mathrm{ppm})\end{array}$ & $\underset{(\mathrm{ppm})}{\mathrm{Ag}}$ & $\begin{array}{c}\text { As } \\
\text { (ppm) }\end{array}$ & $\begin{array}{l}\mathrm{Sb} \\
(\mathrm{ppm})\end{array}$ & $\begin{array}{c}S \\
(\%)\end{array}$ \\
\hline $\begin{array}{c}\text { M73-11- } \\
336\end{array}$ & $\begin{array}{c}\text { Oolitic } \\
\text { Calcarenite }\end{array}$ & $x$ & & $x$ & & 17.45 & 3.07 & 41.2 & 1.1 & 0.91 & 0.13 & 375 & $<0.5$ & 16.2 & 0.16 & 0.09 \\
\hline $\begin{array}{l}\text { M73-11- } \\
347\end{array}$ & $\begin{array}{c}\text { Oolitic } \\
\text { Calcarenite }\end{array}$ & $X$ & & $X$ & & 7.59 & 0.97 & 50.2 & 0.61 & 0.33 & 0.05 & 6420 & 30 & 3.7 & 0.06 & 0.28 \\
\hline $\begin{array}{l}\text { M73-11- } \\
359\end{array}$ & $\begin{array}{c}\text { Oolitic } \\
\text { Calcarenite }\end{array}$ & $x$ & & $X$ & & 5.27 & 0.8 & 50.7 & 0.82 & 0.29 & 0.03 & 2540 & 8 & 4.3 & 0.24 & 0.13 \\
\hline $\begin{array}{c}\text { M73-11- } \\
404\end{array}$ & $\begin{array}{c}\text { Uniform } \\
\text { Calcarenite } \\
\text { Upper }\end{array}$ & $x$ & & $x$ & & 7.33 & 0.86 & 49.1 & 1.05 & 0.3 & 0.05 & 843 & 0.6 & 15.1 & 0.1 & 0.13 \\
\hline $\begin{array}{l}\text { M73-11- } \\
422\end{array}$ & $\begin{array}{l}\text { Transition } \\
\text { Series }\end{array}$ & & & $x$ & $x$ & 32 & 7.62 & 26.3 & 1.63 & 2.58 & 0.39 & $>10,000$ & 57.6 & 10.3 & 0.23 & 0.6 \\
\hline $\begin{array}{c}\text { M73-11- } \\
431\end{array}$ & $\begin{array}{c}\text { Upper } \\
\text { Transition } \\
\text { Series }\end{array}$ & & & $x$ & & 29.7 & 1.4 & 31.5 & 1.67 & 0.1 & 0.08 & 1070 & 1 & 0.5 & 0.07 & 0.11 \\
\hline $\begin{array}{l}\text { M73-11- } \\
442\end{array}$ & $\begin{array}{l}\text { Lower } \\
\text { Transition } \\
\text { Series }\end{array}$ & & & $x$ & & 71 & 10.4 & 4.71 & 0.63 & 3.42 & 0.51 & $>10,000$ & $>100$ & $>250$ & $>250$ & 0.89 \\
\hline $\begin{array}{l}\text { M73-11- } \\
450\end{array}$ & $\begin{array}{l}\text { Lower } \\
\text { Transition } \\
\text { Series }\end{array}$ & & & $X$ & & 86.4 & 6.06 & 0.97 & 0.14 & 2.56 & 0.17 & 5910 & 26 & 155.5 & 3.25 & 0.28 \\
\hline $\begin{array}{l}\text { M73-11- } \\
498\end{array}$ & $\begin{array}{l}\text { Old Red } \\
\text { Sandstone }\end{array}$ & $x$ & & $x$ & $x$ & 52.6 & 9.46 & 6.28 & 1.21 & 3.51 & 0.55 & 13 & $<0.5$ & 1.6 & 0.37 & 2.18 \\
\hline $\begin{array}{l}\text { M73-11- } \\
510\end{array}$ & $\begin{array}{l}\text { Old Red } \\
\text { Sandstone }\end{array}$ & $x$ & & $x$ & & 65.6 & 3.55 & 8.19 & 1.31 & 1.48 & 0.14 & 6 & $<0.5$ & 0.7 & $<0.05$ & 1.46 \\
\hline $\begin{array}{c}\text { M73-19- } \\
072\end{array}$ & $\begin{array}{c}\text { Oolitic } \\
\text { Calcarenite }\end{array}$ & $x$ & & $X$ & $x$ & 18.05 & 4.32 & 41.8 & 0.79 & 1.33 & 0.24 & 8460 & 12.3 & 9.5 & 2.29 & 0.99 \\
\hline $\begin{array}{c}\text { M73-19- } \\
133\end{array}$ & $\begin{array}{l}\text { Lower Shaly } \\
\text { Calcarenite }\end{array}$ & $x$ & $x$ & $x$ & $x$ & 13.05 & 1.45 & 46.2 & 0.67 & 0.49 & 0.09 & $>10,000$ & 79 & 10.2 & 0.27 & 0.56 \\
\hline $\begin{array}{c}\text { M73-19- } \\
142\end{array}$ & $\begin{array}{c}\text { Lower Shaly } \\
\text { Calcarenite }\end{array}$ & $x$ & & & & & & & & & & & & & & \\
\hline $\begin{array}{c}\text { M73-19- } \\
172\end{array}$ & $\begin{array}{l}\text { Uniform } \\
\text { Calcarenite }\end{array}$ & $x$ & & & & & & & & & & & & & & \\
\hline $\begin{array}{l}\text { M73-19- } \\
249\end{array}$ & $\begin{array}{l}\text { Lower } \\
\text { Transition } \\
\text { Series }\end{array}$ & $x$ & & $x$ & $x$ & 75.1 & 11.8 & 0.91 & 0.58 & 3.95 & 0.68 & $>10,000$ & 95.5 & $>250$ & $>250$ & 0.66 \\
\hline $\begin{array}{l}\text { M73-19- } \\
257\end{array}$ & $\begin{array}{l}\text { Lower } \\
\text { Transition } \\
\text { Series }\end{array}$ & $x$ & $x$ & $x$ & $x$ & 75.9 & 11.05 & 1.87 & 0.94 & 3.77 & 0.56 & 7050 & 45.3 & $>250$ & 146.5 & 0.38 \\
\hline $\begin{array}{c}\text { M73-19- } \\
264\end{array}$ & $\begin{array}{l}\text { Lower } \\
\text { Transition } \\
\text { Series }\end{array}$ & $x$ & & & & & & & & & & & & & & \\
\hline
\end{tabular}


Table A3. Cont.

\begin{tabular}{|c|c|c|c|c|c|c|c|c|c|c|c|c|c|c|c|c|}
\hline Samples & & Petrog. & EDS & Assay & $\begin{array}{l}\text { micro- } \\
\text { XRF }\end{array}$ & $\begin{array}{c}\mathrm{SiO}_{2} \\
(\%)\end{array}$ & $\begin{array}{c}\mathrm{Al}_{2} \mathrm{O}_{3} \\
(\%)\end{array}$ & $\begin{array}{c}\mathrm{CaO} \\
(\%)\end{array}$ & $\begin{array}{c}\mathrm{MgO} \\
(\%)\end{array}$ & $\begin{array}{c}\mathrm{K}_{2} \mathrm{O} \\
(\%)\end{array}$ & $\begin{array}{c}\mathrm{TiO}_{2} \\
(\%)\end{array}$ & $\begin{array}{c}\mathrm{Cu} \\
(\mathrm{ppm})\end{array}$ & $\underset{(\mathrm{ppm})}{\mathrm{Ag}}$ & $\begin{array}{c}\text { As } \\
(\mathrm{ppm})\end{array}$ & $\begin{array}{c}\mathrm{Sb} \\
(\mathrm{ppm})\end{array}$ & $\begin{array}{c}S \\
(\%)\end{array}$ \\
\hline $\begin{array}{c}\text { M73-19- } \\
271\end{array}$ & $\begin{array}{c}\text { Lower } \\
\text { Transition } \\
\text { Series }\end{array}$ & $x$ & & & & & & & & & & & & & & \\
\hline $\begin{array}{c}\text { M73-19- } \\
279\end{array}$ & $\begin{array}{l}\text { Lower } \\
\text { Transition } \\
\text { Series }\end{array}$ & $x$ & & & & & & & & & & & & & & \\
\hline $\begin{array}{l}\text { M73-19- } \\
296\end{array}$ & $\begin{array}{l}\text { Lower } \\
\text { Transition } \\
\text { Series }\end{array}$ & $x$ & & $x$ & & 87.2 & 3.63 & 4.03 & 0.43 & 1.74 & 0.06 & 1280 & 3.6 & $>250$ & 119 & 0.08 \\
\hline
\end{tabular}

\section{References}

1. Singer, D.A. World class base and precious metal deposits-A quantitative analysis. Econ. Geol. 1995, 90, 88-104. [CrossRef]

2. Andrew, C.J. The tectono-stratigraphic controls to mineralization in the Silvermines area, County Tipperary, Ireland. In Geology and Genesis of Mineral Deposits in Ireland; Andrew, C.J., Crowe, R.W.A., Finlay, S., Pennel, W.M., Pyne, J.F., Eds.; Irish Association for Economic Geology: Dublin, Ireland, 1986; pp. 377-417.

3. Shearley, E.; Redmon, P.; King, M.; Goodman, R. Geological controls on mineralization and dolomitization of the Lisheen Zn-Pb-Ag deposit, Co. Tipperary, Ireland. Geol. Soc. Lond. Spec. Publ. 1996, 107, 23-33. [CrossRef]

4. Ashton, J.H.; Blakeman, R.J.; Geraghty, J.F.; Beach, A.; Coller, D.; Philcox, M.E.; Boyce, A.J.; Wilkinson, J.J. The Giant Navan Carbonate-Hosted Zn-Pb Deposit-A review. In Current Perspectives on Zinc Deposits; Archibald, S.M., Piercey, S.J., Eds.; Irish Association for Economic Geology: Dublin, Ireland, 2015; pp. 85-122. ISBN 978-0-9509894-5-7.

5. Steed, G.M. The geology and genesis of the Gortdrum Cu-Ag-Hg orebody. In Geology and Genesis of Mineral Deposits in Ireland; Andrew, C.J., Crowe, R.W.A., Finlay, S., Pennel, W.M., Pyne, J.F., Eds.; Irish Association for Economic Geology: Dublin, Ireland, 1986; pp. 481-499.

6. Wilbur, D.G.; Carter, J.S. Cu-Ag mineralization at Tullacondra, Mallow, Co. Cork. In Geology and Genesis of Mineral Deposits in Ireland; Andrew, C.J., Crowe, R.W.A., Finlay, S., Pennel, W.M., Pyne, J.F., Eds.; Irish Association for Economic Geology: Dublin, Ireland, 1986; pp. 501-507.

7. Phillips, W.E.A.; Sevastopulo, G.D. The stratigraphic and structural setting of Irish mineral deposits. In Geology and Genesis of Mineral Deposits in Ireland; Andrew, C.J., Crowe, R.W.A., Finlay, S., Pennel, W.M., Pyne, J., Eds.; Irish Association for Economic Geology: Dublin, Ireland, 1986; pp. 1-30.

8. Soper, N.J. Timing and geometry of collision, terrane accretion and sinistral strike-slip events in the British Caledonides. In The Caledonian-Appalachian Orogen; Harris, A.L., Fettes, D.J., Eds.; Geological Society Special Publication: London, UK, 1988; Volume 38, pp. 481-492.

9. Wilkinson, J.J. Sediment-Hosted Zinc-Lead Mineralization: Processes and Perspectives: Processes and Perspectives. In Treatise on Geochemistry: Second Edition; Elsevier Ltd.: Amsterdam, The Netherlands, 2013; Volume 13, pp. 219-249. ISBN 9780080983004.

10. Hudson, R.G.S.; Philcox, M.E. The Lower Carboniferous Stratigraphy of the Buttevant Area, Co. Cork. Proc. R. Ir. Acad. 1964, 64, 65-79.

11. Gardiner, P.R.R.; Maccarthy, I.A.J. The late Palaeozoic evolution of southern Ireland in the context of tectonic basins and their trans-Atlantic significance. In Geology of the North Atlantic Borderlands; Kerr, J.W., Fergus, A.J., Eds.; Memoir of the Canadian Society of Petroleum Geologists: Calgary, AB, Canada, 1981; Volume 7, pp. 683-725.

12. Anderson, I.K.; Ashton, J.H.; Boyce, A.J.; Fallick, A.E.; Russell, M.J. Ore Depositional Processes in the Navan Zn-Pb Deposit, Ireland. Econ. Geol. 1998, 93, 535-563. [CrossRef]

13. Somerville, I.D.; Jones, G.L.I. The Courceyan stratigraphy of the Pallaskenry Borehole, County Limerick, Ireland. Geol. J. 1985, 20, 377-400. [CrossRef]

14. Somerville, I.D.; Strogen, P.; Jones, G.L. Biostratigraphy of Dinantian limestones and associated volcanic rocks in the Limerick Syncline, Ireland. Geol. J. 1992, 27, 201-220. [CrossRef]

15. Strogen, P.; Somerville, I. The stratigraphy of the Upper Palaeozoic rocks of the Lyons Hill area, county Kildare. Ir. Assoc. Econ. Geol. 1984, 6, 155-173.

16. Lees, A.; Miller, J. Facies variation in Waulsortian buildups, Part 2; Mid-Dinantian buildups from Europe and North America. Geol. J. 1985, 20, 159-180. [CrossRef]

17. Gregg, J.M.; Shelton, K.L.; Johnson, A.W.; Somerville, I.D.; Wright, W.R. Dolomitization of the Waulsortian Limestone (Lower Carboniferous) in the Irish Midlands. Sedimentology 2001, 48, 745-766. [CrossRef]

18. Mccusker, J.; Reed, C. The role of intrusions in the formation of Irish-type mineralisation. Miner. Depos. 2013, 48, 687-695. [CrossRef]

19. Wilkinson, J.J.; Hitzman, M.W. The Irish Zn-Pb Orefield: The View from 2014. Ir. Assoc. Econ. Geol. 2015, 59-72.

20. Elliott, H.A.L.; Gernon, T.M.; Roberts, S.; Boyce, A.J.; Hewson, C. Diatremes act as fluid conduits for Zn-Pb mineralization in the SW Irish ore field. Econ. Geol. 2019, 114, 117-125. [CrossRef] 
21. Coller, D.W. Variscan structures in the Upper Palaeozoic rocks of west central Ireland. In Variscan Tectonics of the North Atlantic Region; Hutton, D.J., Sanderson, D.H.W., Eds.; Geological Society of London Special Publication: London, UK, 1984; Volume 14, pp. 185-194.

22. Johnston, J.D.; Coller, D.; Millar, G.; Critchley, M.F. Basement structural controls on Carboniferous-hosted base metal mineral deposits in Ireland. In Geological Society Special Publication; Strogen, P., Somerville, I.D., Jones, G.L., Eds.; Geological Society Special Publication: London, UK, 1996; Volume 107, pp. 1-21.

23. Walsh, J.J.; Torremans, K.; Güven, J.; Kyne, R.; Conneally, J.; Bonson, C. Fault-Controlled Fluid Flow Within Extensional Basins and Its Implications for Sedimentary Rock-Hosted Mineral Deposits. Soc. Econ. Geol. Spec. Publ. 2018, 21, 237-269. [CrossRef]

24. Cooper, M.A.; Collins, D.A.; Ford, M.; Murphy, F.X.; Trayner, P.M.; O'Sullivan, M. Structural evolution of the Irish Variscides. J. Geol. Soc. Lond. 1986, 143, 53-61. [CrossRef]

25. Cooper, M.A.; Collins, D.; Ford, M.; Murphy, F.X.; Trayner, P.M. Structural style, shortening estimates and the thrust front of the Irish Variscides. In Variscan Tectonics of the North Atlantic Region; Hutton, D.J., Sanderson, D.H.W., Eds.; Geological Society of London Special Publication: London, UK, 1984; pp. 167-175.

26. Dolan, J.M. A Structural Cross-Section through the Carboniferous of Northwest Kerry. Ir. J. Earth Sci. 1984, 6, 95-108.

27. Sanderson, D.J. Structural variation across the northern margin of the Variscides in N.W. Europe. In Variscan Tectonics of the North Atlantic Region; Hutton, D.H.W., Sanderson, D.J., Eds.; Geological Society of London Special Publication: London, UK, 1984; Volume 14, pp. 149-165.

28. Kinnaird, J.A.; Ixer, R.A.; Barreiro, B.; Nex, P.A.M. Contrasting sources for lead in Cu-polymetallic and Zn-Pb mineralisation in Ireland: Constraints from lead isotopes. Miner. Depos. 2002, 37, 495-511. [CrossRef]

29. Nex, P.A.M.; Kinnaird, J.A.; Ixer, R.A. Localized ductile thrusting north of the Variscan Front, Ross Island, southwest Ireland. Geol. J. 2003, 38, 15-29. [CrossRef]

30. Todd, S.P. Structure of the Dingle Peninsula, SW Ireland: Evidence for the nature and timing of Caledonian, Acadian and Variscan tectonics. Geol. Mag. 2015, 152, 242-268. [CrossRef]

31. Maccarthy, I.A.J.; Meere, P.A. Geology of the Devonian-Carboniferous South Munster Basin, Ireland-Explanatory Notes to Accompany 1:75,000 Scale Geological Map (2004 Edition) Sedimentary Provenance of Southern Irish Onshore and Offshore Basins View Project; University College Cork/National University of Ireland: Cork, Ireland, 2004.

32. Fusciardi, L.P.; Güven, J.F.; Stewart, D.R.A.; Carboni, V.; Walsh, J.J. The geology and genesis of the Lisheen Zn-Pb deposit, Co. Tipperary, Ireland. In Europe's Major Base Metal Deposits; Kelly, J.G., Andrew, C.J., Ashton, J.H., Boland, M.B., Earls, G., Fusciardi, L., Stanley, G., Eds.; Special Publication of the Irish Association for Economic Geology: Dublin, Ireland, 2003 ; pp. 455-482.

33. Reed, C.P.; Wallace, M.W. Zn-Pb mineralisation in the Silvermines district, Ireland: A product of burial diagenesis. Miner. Depos. 2004, 39, 87-102. [CrossRef]

34. Torremans, K.; Gauquie, J.; Boyce, A.J.; Barrie, C.D.; Dewaele, S.; Sikazwe, O.; Muchez, P. Remobilisation features and structural control on ore grade distribution at the Konkola stratiform Cu-Co ore deposit, Zambia. J. Afr. Earth Sci. 2013, 79, 10-23. [CrossRef]

35. Kyne, R.; Torremans, K.; Güven, J.; Doyle, R.; Walsh, J. 3-D modeling of the Lisheen and Silvermines deposits, County Tipperary, Ireland: Insights into structural controls on the formation of Irish Zn-Pb deposits. Econ. Geol. 2019, 114, 93-116. [CrossRef]

36. Hitzman, M.W.; Redmond, P.B.; Beaty, D.W. The carbonate-hosted Lisheen Zn-Pb-Ag deposit, County Tipperary, Ireland. Econ. Geol. 2002, 97, 1627-1655. [CrossRef]

37. Lee, M.J.; Wilkinson, J.J. Cementation, hydrothermal alteration, and $\mathrm{Zn}-\mathrm{Pb}$ mineralization of carbonate breccias in the Irish Midlands: Textural evidence from the cooleen zone, near Silvermines, county Tipperary. Econ. Geol. 2002, 97, 653-662. [CrossRef]

38. Yesares, L.; Drummond, D.A.; Hollis, S.P.; Doran, A.L.; Menuge, J.F.; Boyce, A.J.; Blakeman, R.J.; Ashton, J.H. Coupling mineralogy, textures, stable and radiogenic isotopes in identifying ore-forming processes in Irish-Type Carbonate-hosted $\mathrm{Zn}-\mathrm{Pb}$ deposits. Minerals 2019, 9, 335. [CrossRef]

39. Boast, A.M.; Coleman, M.L.; Halls, C. Textural and stable isotopic evidence for the genesis of the Tynagh base metal deposit, Ireland. Econ. Geol. 1981, 76, 27-55. [CrossRef]

40. Wilkinson, J.J.; Eyre, S.L.; Boyce, A.J. Ore-forming processes in Irish-Type Carbonate-hosted Zn-Pb deposits: Evidence from mineralogy, chemistry, and isotopic composition of sulfides at the Lisheen mine. Econ. Geol. 2005, 100, 63-86. [CrossRef]

41. Andrew, C.J. The geological setting and style of mineralization at Ballyvergin, County Clare. In Geology and Genesis of Mineral Deposits in Ireland; Andrew, C.J., Crowe, R.W.A., Pennell, W.M., Pyne, J.F., Eds.; Irish Association for Economic Geology: Dublin, Ireland, 1986; pp. 475-480.

42. Duane, M.J. Genesis, mineralogy and geochemistry of uranium in the Gortdrum stratiform copper deposit, Ireland. Miner. Depos. 1988, 23, 50-57. [CrossRef]

43. Romer, D. A note on Aherlow Cu-Ag deposit, County Limerick. In Geology and Genesis of Mineral Deposits in Ireland; Andrew, C.J., Crowe, R.W.A., Finlay, S., Pennel, W.M., Pyne, J.F., Eds.; Irish Association for Economic Geology: Dublin, Ireland, 1986; pp. 509-511.

44. Johnston, J.D. Regional fluid flow and the genesis of Irish Carboniferous base metal deposits. Miner. Depos. 1999, 34, 571-598. [CrossRef]

45. Lang, J.; Meere, P.A.; Unitt, R.P.; Johnson, S.C.; Torremans, K.; Selby, D.; Kyne, R. The vein hosted copper deposits of the Allihies Mining area, Southwest Ireland-A new structural and chronological evaluation. J. Geol. Soc. Lond. 2020, 177, 671-685. [CrossRef] 
46. Hnatyshin, D.; Creaser, R.A.; Wilkinson, J.J.; Gleeson, S.A. Re-Os dating of pyrite confirms an early diagenetic onset and extended duration of mineralization in the Irish $\mathrm{Zn}-\mathrm{Pb}$ ore field. Geology 2015, 43, 143-146. [CrossRef]

47. Philcox, M.E. Lower Carboniferous Lithostratigraphy of the Irish Midlands; Irish Association for Economic Geology: Dublin, Ireland, 1984.

48. Strogen, P.; Jones, G.L.; Somerville, I. Stratigraphy and sedimentology of lower carboniferous (Dinantian) boreholes from West Co. Meath, Ireland. Geol. J. 1990, 25, 103-137. [CrossRef]

49. Torremans, K.; Kyne, R.; Doyle, R.; Güven, J.F.; Walsh, J.J. Controls on metal distributions at the Lisheen and Silvermines deposits: Insights into fluid flow pathways in Irish-Type Zn-Pb deposits. Econ. Geol. 2018, 113, 1455-1477. [CrossRef]

50. Pracht, M. Geology of Kerry-Cork; Geological Survey of Ireland: Dublin, Ireland, 1997.

51. Whitney, D.L.; Evans, B.W. Abbreviations for names of rock-forming minerals. Am. Mineral. 2010, 95, 185-187. [CrossRef]

52. Çimen, O.; Kuebler, C.; Simonetti, S.S.; Corcoran, L.; Mitchell, R.; Simonetti, A. Combined boron, radiogenic (Nd, Pb, Sr), stable (C, $\mathrm{O})$ isotopic and geochemical investigations of carbonatites from the Blue River Region, British Columbia (Canada): Implications for mantle sources and recycling of crustal carbon. Chem. Geol. 2019, 529, 1-18. [CrossRef]

53. Corcoran, L.; Simonetti, A.; Spano, T.L.; Lewis, S.R.; Dorais, C.; Simonetti, S.; Burns, P.C. Multivariate analysis based on geochemical, isotopic, and mineralogical compositions of uranium-rich samples. Minerals 2019, 9, 537. [CrossRef]

54. A.L.S. Global Geochemistry Schedule of Services and Fees USD. Available online: https://www.alsglobal.com/en/services-andproducts / geochemistry/geochemistry-downloads (accessed on 23 May 2021).

55. Turner, O.; Hollis, S.; Güven, J.; Mcclenaghan, S. Establishing a geochemical baseline for the Lower Carboniferous stratigraphy of the Rathdowney Trend, Irish Zn-Pb orefield. J. Geochem. Explor. 2019, 196, 259-269. [CrossRef]

56. Wilkinson, J.J.; Crowther, H.L.; Coles, B.J. Chemical mass transfer during hydrothermal alteration of carbonates: Controls of seafloor subsidence, sedimentation and $\mathrm{Zn}-\mathrm{Pb}$ mineralization in the Irish Carboniferous. Chem. Geol. 2011, 289, 55-75. [CrossRef]

57. Blakeman, R.J.; Ashton, J.H.; Boyce, A.J.; Fallick, A.E.; Russell, M.J. Timing of interplay between hydrothermal and surface fluids in the Navan $\mathrm{Zn}+\mathrm{Pb}$ orebody, Ireland: Evidence from metal distribution trends, mineral textures, and $\delta 34 \mathrm{~S}$ analyses. Econ. Geol. 2002, 97, 73-91. [CrossRef]

58. Everett, C.E.; Rye, D.M.; Ellam, R.M. Source or Sink? An Assessment of the Role of the Old Red Sandstone in the Genesis of the Irish Zn-Pb Deposits. Econ. Geol. 2003, 98, 31-50.

59. Hitzman, M.W.; Selley, D.; Bull, S. Formation of Sedimentary Rock-Hosted Stratiform Copper Deposits through Earth History. Econ. Geol. 2010, 105, 627-639. [CrossRef]

60. Peace, W.M.; Wallace, M.W.; Holdstock, M.P.; Ashton, J.H. Ore textures within the U lens of the Navan Zn-Pb deposit, Ireland. Miner. Depos. 2003, 38, 568-584. [CrossRef]

61. Cordeiro, P.; Santos, A.M.; Steed, G.M.; Silva, A.A.; Meere, P.A.; Corcoran, L.; Simonetti, A.; Unitt, R. The carbonate-hosted Gortdrum Cu-Ag $( \pm \mathrm{Sb}-\mathrm{Hg})$ deposit, SW Ireland: C-O-Sr-Nd isotopes and whole-rock geochemical signatures. Ore Geol. Rev.. under review.

62. Flügel, E. Diagenesis, Porosity, and Dolomitization. In Microfacies of Carbonate Rocks Analysis, Interpretation and Application; Springer: Berlin, Germany, 2004; pp. 267-338.

63. Price, C.A.; Todd, S.P. A model for the development of the Irish Variscides. J. Geol. Soc. 1988, 145, 935-939. [CrossRef] 